\title{
Impaired HMG-CoA Reductase Activity Caused by Genetic Variants or Statin Exposure: Impact on Human Adipose Tissue, $\beta$-Cells and Metabolome
}

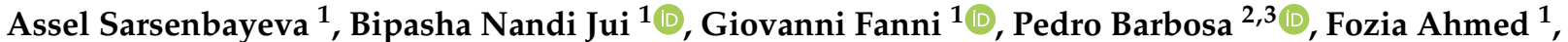 \\ Robin Kristófi ${ }^{1}$, Jing Cen ${ }^{4}$, Azazul Chowdhury ${ }^{4}$, Stanko Skrtic ${ }^{5,6}$, Peter Bergsten ${ }^{4}$, Tove Fall ${ }^{1}$, Jan W. Eriksson ${ }^{1}$ \\ and Maria J. Pereira $1, *$ (D)
}

\section{check for} updates

Citation: Sarsenbayeva, A.; Jui, B.N.; Fanni, G.; Barbosa, P.; Ahmed, F.; Kristófi, R.; Cen, J.; Chowdhury, A.; Skrtic, S.; Bergsten, P.; et al. Impaired HMG-CoA Reductase Activity Caused by Genetic Variants or Statin Exposure: Impact on Human Adipose Tissue, $\beta$-Cells and Metabolome. Metabolites 2021, 11, 574. https:// doi.org/10.3390/metabo11090574

Academic Editor: Amedeo Lonardo

Received: 23 July 2021

Accepted: 18 August 2021

Published: 25 August 2021

Publisher's Note: MDPI stays neutral with regard to jurisdictional claims in published maps and institutional affiliations.

Copyright: (C) 2021 by the authors. Licensee MDPI, Basel, Switzerland. This article is an open access article distributed under the terms and conditions of the Creative Commons Attribution (CC BY) license (https:// creativecommons.org/licenses/by/ $4.0 /)$
1 Department of Medical Sciences, Clinical Diabetology and Metabolism, Uppsala University, 75185 Uppsala, Sweden; assel.sarsenbayeva@medsci.uu.se (A.S.);

Bipasha.Nandijui.2754@student.uu.se (B.N.J.); giovanni.fanni@medsci.uu.se (G.F.); fozia.ahmed@medsci.uu.se (F.A.); robin.kristofi@medsci.uu.se (R.K.); tove.fall@medsci.uu.se (T.F.); jan.eriksson@medsci.uu.se (J.W.E.)

2 Center for Neuroscience and Cell Biology, University of Coimbra, 3004-504 Coimbra, Portugal; pedrobarbosa13@hotmail.com

3 Institute for Interdisciplinary Research, University of Coimbra, 3030-789 Coimbra, Portugal

4 Department of Medical Cell Biology, Uppsala University, 75185 Uppsala, Sweden; jing.cen@mcb.uu.se (J.C.); azazul.chowdhury@mcb.uu.se (A.C.); peter.bergsten@mcb.uu.se (P.B.)

5 Innovation Strategies \& External Liaison, Pharmaceutical Technologies \& Development, AstraZeneca, 43183 Gothenburg, Sweden; Stanko.Skrtic@astrazeneca.com

6 Institute of Medicine at Sahlgrenska Academy, University of Gothenburg, 41345 Gothenburg, Sweden

* Correspondence: maria.pereira@medsci.uu.se; Tel.: +46-18-471-4712

Abstract: Inhibition of 3-hydroxy-3-methyl-glutaryl-CoA (HMG-CoA) reductase is associated with an increased risk of new-onset type 2 diabetes. We studied the association of genetic or pharmacological HMG-CoA reductase inhibition with plasma and adipose tissue (AT) metabolome and AT metabolic pathways. We also investigated the effects of statin-mediated pharmacological inhibition of HMG-CoA reductase on systemic insulin sensitivity by measuring the HOMA-IR index in subjects with or without statin therapy. The direct effects of simvastatin $(20-250 \mathrm{nM})$ or its active metabolite simvastatin hydroxy acid (SA) (8-30 nM) were investigated on human adipocyte glucose uptake, lipolysis, and differentiation and pancreatic insulin secretion. We observed that the LDL-lowering HMGCR rs12916-T allele was negatively associated with plasma phosphatidylcholines and sphingomyelins, and HMGCR expression in AT was correlated with various metabolic and mitochondrial pathways. Clinical data showed that statin treatment was associated with HOMA-IR index after adjustment for age, sex, BMI, HbA1c, LDL-c levels, and diabetes status in the subjects. Supratherapeutic concentrations of simvastatin reduced glucose uptake in adipocytes and normalized fatty acid-induced insulin hypersecretion from $\beta$-cells. Our data suggest that inhibition of HMG-CoA reductase is associated with insulin resistance. However, statins have a very mild direct effect on AT and pancreas, hence, other tissues as the liver or muscle appear to be of greater importance.

Keywords: statins; adipose tissue; $\beta$-cell; insulin resistance; glucose uptake; type 2 diabetes

\section{Introduction}

3-hydroxy-3-methyl-glutaryl-CoA reductase (HMG-CoA reductase, HMGCR) is a rate-limiting enzyme involved in the mevalonate pathway responsible for the synthesis of cholesterol, which is a vital precursor of different biologically active molecules, such as steroid hormones and lipoproteins [1]. Statins are lipid-lowering drugs, which potently inhibit the activity of HMG-CoA reductase and effectively reduce the plasma concentration of LDL cholesterol. Since statins reduce the risk of cardiovascular events and overall mortality in the patients [2], they are one of the most widely prescribed drugs in the world. 
For instance, in the USA, the number of adults taking statins increased from 21.8 million in 2002-2003 to 39.2 million in 2012-2013 [3]. Apart from reducing plasma cholesterol levels, statins inhibit the synthesis of other components of the mevalonate pathway, such as major isoprenoids, farnesyl and geranylgeranyl pyrophosphate [1,4]. Aberrant synthesis of these compounds contributes to the development of different disorders, including cancer, cerebrovascular diseases, and Alzheimer's disease [4]. Statins' anti-neoplastic, anti-inflammatory, and cardioprotective functions make them a potential therapeutic agent for these conditions [5]. Despite being generally safe and well-tolerated, statin therapy is associated with an increased risk of new-onset type 2 diabetes (T2D) [6]. Several preexisting risk factors can stimulate the diabetogenic potential of the therapy, including therapy intensity, some genetic predisposition, sex, and age of the patients [6-10]. Statins with high or moderate potency, such as atorvastatin and simvastatin, are reported to have a higher propensity to induce new-onset diabetes in patients compared to low potency statins, e.g., fluvastatin [9]. Comparison between statins indicated that patients taking atorvastatin or simvastatin have increased risk of new-onset diabetes [9], reduced insulin secretion, and insulin sensitivity [11]. On the other hand, pravastatin is considered protective against diabetes development $[9,12,13]$. This could be due to the lipophilicity of the drugs, as lipophilic statins (e.g., atorvastatin and simvastatin) can pass through the cell membrane of extrahepatic tissues, such as the pancreas, unlike hydrophilic statins (pravastatin) [14], which could contribute to their diabetogenic effect.

Additionally, the rs 12916 HMGCR polymorphism is associated with reduced hepatic HMGCR expression and reduced LDL-cholesterol levels, as well as increased diabetes risk [15]. Genetic inhibition of HMG-CoA reductase due to this polymorphism appears to resemble metabolic side effects of statin therapy. Therefore, it is of interest to understand whether the association of HMGCR and its LDL-lowering polymorphism with certain plasma or adipose tissue metabolites could give a closer insight into the diabetogenic effects of statins.

Several possible mechanisms for the diabetogenic actions of statins have been proposed. Pancreatic $\beta$-cells are capable of de novo cholesterol synthesis. Inhibition of cholesterol production leads to deprivation of plasma membrane cholesterol, increased LDL receptor expression and increased uptake of plasma LDL in the $\beta$-cells $[16,17]$. Accumulating LDL in the $\beta$-cells from the bloodstream seems to induce inflammation and apoptosis of mice and human pancreatic $\beta$-cells and, hence, impair their function $[16,18]$. In vitro and animal studies on skeletal muscle cells have shown that simvastatin reduced glucose transporter 4 (GLUT4) translocation and impaired glucose uptake via interfering with insulin signaling cascade $[19,20]$. Animal studies have also demonstrated that the mevalonate pathway and its components seem to be highly important for the metabolic functions of adipose tissue [21,22]. Studies have also demonstrated that supra-therapeutic concentrations of statins (atorvastatin and simvastatin) inhibited 3T3-L1 adipocyte differentiation and GLUT4 translocation in adipocytes as well [23,24]. Interestingly, most studies have been performed in vitro using concentrations of statins in the range of 1-50 $\mu \mathrm{M}$, which is more than 1000 times higher than the concentrations seen in human plasma [25]. Similarly, the authors report that animal studies also use a much higher dose than the dose administered to the patients (1-100 mg/ $\mathrm{kg}$ vs. $0.1-1 \mathrm{mg} / \mathrm{kg}$, respectively) [25]. Therefore, studies with relevant therapeutic concentrations are warranted. Finally, most of the studies use simvastatin lactone, which is an inactive prodrug [25], therefore, its active metabolite, simvastatin hydroxy acid, also needs to be tested.

We hypothesize that inhibition of HMG-CoA reductase has a negative impact on plasma and adipose tissue metabolome and human adipose tissue metabolism, and pancreatic islet function. Therefore, our work aims to study the direct effects of pharmacological inhibition of HMG-CoA reductase with statins (simvastatin and its active metabolite simvastatin hydroxy acid) on human subcutaneous adipose tissue and isolated human pancreatic islet function. The concentration of the drugs was selected according to the reported therapeutic concentrations to perform clinically relevant experiments. Furthermore, 
we investigated the impact of a genetic HMGCR variant lowering LDL-cholesterol levels on the circulating metabolome.

\section{Results}

We aimed to study the association of HMG-CoA reductase with adipose tissue and plasma metabolome and to understand whether genetic and pharmacological inhibition of the enzyme would affect the circulating metabolome or aggravate whole-body metabolism. For this, we performed the following human studies.

\subsection{Association Studies}

2.1.1. Association of Expression of HMGCR and Other Genes and Metabolites in Adipose Tissue

To study the association of HMGCR with adipose tissue metabolic pathways, we performed multiple regression analysis between the expression of HMGCR and other genes in the adipose tissue from 31 statin-free subjects. The multiple regression analysis was adjusted for BMI, sex, age, and diabetes status. The data showed 7659 genes significantly associated with HMGCR expression in adipose tissue. However, after adjusting the regression $p$-values with the Benjamini-Hochberg method, the number of significantly associated genes was 5851. Among these, 2652 genes showed a strong positive association and 3199 genes a strong negative association with HMGCR mRNA. The software mapped 2065 positively and 2228 negatively associated genes with the correspondent $p$-values to the protein interaction network and performed an active subnetwork search. After filtering and enriching the active subnetworks with the KEGG gene set, 219 positively associated and 151 negatively associated enriched terms were identified, and among these: metabolic pathways, glucagon and insulin signaling, adipocytokine signaling, oxidative phosphorylation, and citrate cycle. Relevant enriched terms related to metabolism are shown in Figure 1.

Some of the pathways, for instance, insulin signaling, insulin resistance or adipocytokine signaling appear among both positively and negatively associated terms. This is due to the association of $H M G C R$ with genes that are involved in different signaling subpathways within the same enriched term. For example, HMGCR is positively associated with: PI3K, JNK, CD36, STAT3, ADIPOQ genes, while it is negatively associated with mTOR, AMPK, and PEPCK genes. All these genes appear in adipocytokine signaling as well as insulin signaling or insulin resistance. A detailed list of genes can be found in Supplementary Table S1.

To understand whether HMGCR expression is changed in patients with diabetes, we compared the HMGCR adipose tissue gene expression between healthy subjects and individuals with T2D. We did not observe any significant difference in HMGCR expression between the two groups. When comparing the expression of HMGCR in the adipose tissue of patients taking statins $(n=9)$ vs. statin-free $(n=31)$ individuals, the expression of $H M G C R$ was 3 -fold higher in the first groups $(p<0.05)$ (data not shown). 


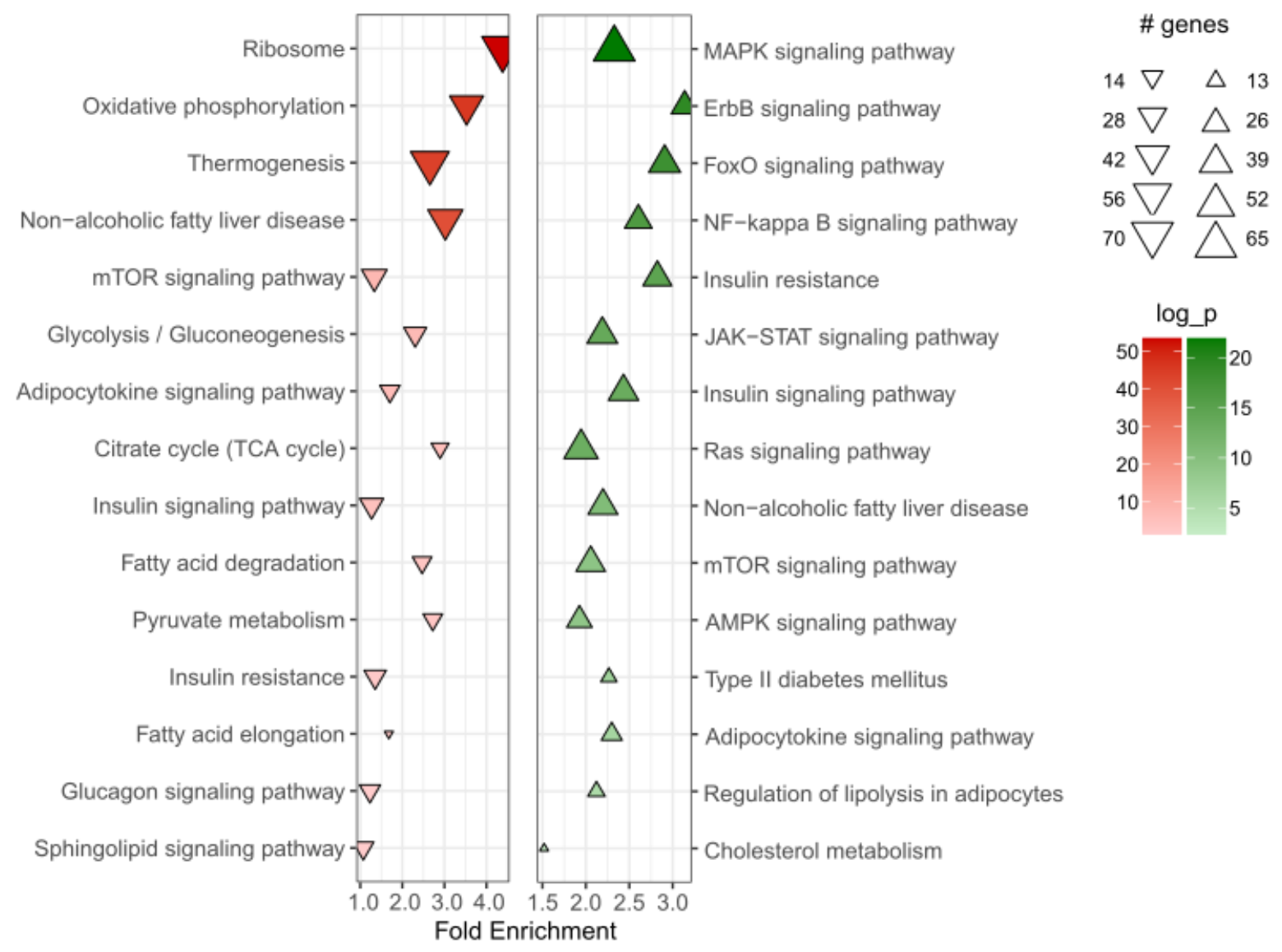

Figure 1. HMGCR expression in adipose tissue is associated with the indicated enriched terms identified based on KEGG database. The graph shows a list of positively (green) and negatively (red) associated terms. The complete list of all the enriched terms is provided in Supplementary Figures S1 and S2.

We also performed multiple regression analyses of adipose tissue HMGCR expression with adipose tissue metabolites. The data showed that HMGCR expression correlated with 31 metabolites in adipose tissue. HMGCR expression negatively correlated with sphingomyelin. In addition, there was a positive association with phosphatidylserine, total triacylglycerol, and several free fatty acids (e.g., pentadecanoic acid, eicosaenoic acid). However, the association was not significant after multiplicity adjustment with the Benjamini-Hochberg method (data not shown).

\subsubsection{Association of Expression of $H M G C R$ and Plasma Metabolites}

To investigate the effects of genetic inhibition of HMGCR on circulating metabolome, we studied the association of the LDL-lowering HMGCR rs12916-T allele, representing genetic inhibition of HMG-CoA reductase, with publicly annotated 174 blood metabolites quantified in large-scale population-based studies [26]. We found a negative association with phosphatidylcholines and sphingomyelins in the blood (Table 1). 
Table 1. List of metabolites in the blood associated with HMGCR rs12916-T allele.

\begin{tabular}{ccccc}
\hline Metabolite & Metabolite Class & Z Score & $p$-Value & Adj. $p$-Value \\
\hline PC aa C36:3 & Phosphatidylcholines & -3.236 & 0.0012 & 0.0014 \\
SM C24:0 & Sphingomyelins & -3.24 & 0.0012 & 0.0029 \\
PC ae C34:2 & Phosphatidylcholines & -3.13 & 0.0017 & 0.0043 \\
PC aa C36:2 & Phosphatidylcholines & -3.12 & 0.0018 & 0.0057 \\
PC aa C34:3 & Phosphatidylcholines & -3.067 & 0.0022 & 0.0072 \\
PC ae C40:4 & Phosphatidylcholines & -3.057 & 0.0022 & 0.0086 \\
PC aa C32:3 & Phosphatidylcholines & -2.956 & 0.0031 & 0.0101 \\
PC ae C32:2 & Phosphatidylcholines & -2.955 & 0.0031 & 0.0115 \\
PC aa C26:0 & Phosphatidylcholines & -2.873 & 0.0041 & 0.0129 \\
PC ae C34:1 & Phosphatidylcholines & -2.828 & 0.0047 & 0.0144 \\
PC ae C36:2 & Acylcarnitines & -2.809 & 0.005 & 0.0158 \\
PC aa C28:1 & Phosphatidylcholines & -2.807 & 0.005 & 0.0172 \\
PC ae C44:3 & Phosphatidylcholines & -2.766 & 0.0057 & 0.0187 \\
PC aa C34:1 & Phosphatidylcholines & -2.69 & 0.0072 & 0.0201 \\
Octadecanoylcarnitine & Phosphatidylcholines & -2.676 & 0.0074 & 0.0216 \\
PC aa C30:0 & Acylcarnitines & -2.614 & 0.009 & 0.0230 \\
Asparagine & Phosphatidylcholines & -2.599 & 0.0094 & 0.0244 \\
Dodecanoylcarnitine & Amino acids & 2.594 & 0.0095 & 0.0259 \\
\hline
\end{tabular}

PC aa—Phosphatidylcholine with diacyl residue; PC ae—Phosphatidylcholine with acyl-alkyl residue; SM—sphingomyelin.

\subsubsection{Association of HMGCR SNP rs12916 with Diabetes and Diabetes-Related Traits}

We also studied the association of the T allele of the HMGCR polymorphism rs12916 with diabetes and cardiometabolic traits. The results are shown in Table 2. We observed that despite being associated with lower HMGCR activity, lower LDL-c levels, and coronary artery disease risk, the rs12916-T allele is associated with a higher risk of type 2 diabetes and several diabetes-associated traits, including increased BMI and body fat \% (Table 2).

Table 2. Association of the T-allele of rs12916 (Chr. 5, position: 74656539) with diabetes and diabetes-related traits in large published GWAS.

\begin{tabular}{|c|c|c|c|c|c|c|}
\hline Trait & Unit & Study PMID & Beta & $p$-Value & Adj.p-Value & $n$ \\
\hline $\begin{array}{l}2 \mathrm{~h} \text { fasting } \\
\text { glucose }\end{array}$ & $\mathrm{mmol} / \mathrm{L}$ & $22,885,924$ & 0.02 & 0.14 & 1 & 42,854 \\
\hline $\begin{array}{l}\text { Body fat } \\
\text { percentage }\end{array}$ & IVNT & $\mathrm{UKBB}$ * & 0.01 & $1.4 \times 10^{-9}$ & $1.6 \times 10^{-8}$ & 331,117 \\
\hline $\begin{array}{l}\text { Body mass } \\
\text { index }\end{array}$ & IVNT & $25,673,413$ & 0.02 & $7.3 \times 10^{-9}$ & $8.0 \times 10^{-8}$ & 315,585 \\
\hline $\begin{array}{c}\text { Coronary artery } \\
\text { disease }\end{array}$ & $\log \mathrm{OR}$ & $28,530,674$ & -0.04 & $7.6 \times 10^{-6}$ & $8.4 \times 10^{-5}$ & 214,613 \\
\hline Fasting glucose & $\mathrm{mmol} / \mathrm{L}$ & $22,885,924$ & 0.00 & 0.86 & 1 & 133,010 \\
\hline $\begin{array}{l}\text { High density } \\
\text { lipoprotein }\end{array}$ & IVNT & $24,097,068$ & 0.00 & 0.20 & 1 & 187,167 \\
\hline $\begin{array}{l}\text { Hip } \\
\text { circumference }\end{array}$ & IVNT & $25,673,412$ & 0.02 & $2.80 \times 10^{-5}$ & $3.1 \times 10^{-4}$ & 213,038 \\
\hline $\begin{array}{l}\log \text { Fasting } \\
\text { insulin }\end{array}$ & $\mathrm{pmol} / \mathrm{L}$ & $22,885,924$ & 0.01 & $4.72 \times 10^{-3}$ & 0.05 & 108,557 \\
\hline LDL cholesterol & IVNT & $24,097,068$ & -0.07 & $7.8 \times 10^{-78}$ & $8.6 \times 10^{-77}$ & 168,357 \\
\hline Type 2 diabetes & $\log \mathrm{OR}$ & $25,262,344$ & 0.06 & $9.60 \times 10^{-5}$ & $1.1 \times 10^{-3}$ & 89,371 \\
\hline $\begin{array}{l}\text { Waist } \\
\text { circumference }\end{array}$ & IVNT & $25,673,412$ & 0.02 & $9.70 \times 10^{-7}$ & $1.1 \times 10^{-5}$ & 232,101 \\
\hline
\end{tabular}

* http: / / www.nealelab.is/blog/2017/7/19/rapid-gwas-of-thousands-of-phenotypes-for-337000-samples-in-the-uk-biobank (accessed on 18 August 2021). 


\subsection{Observational Study}

Effects of Statin Treatment on Systemic Insulin Sensitivity

In order to test whether pharmacological inhibition of HMG-CoA reductase would affect systemic insulin sensitivity, we performed an observational study. We compared several metabolic characteristics between 51 patients taking statin therapy and 144 ageand sex-matched individuals in the control group (Table 3). We observed that subjects taking statins show a significant increase in the plasma glucose, $\mathrm{HbA1c}$, insulin levels, as well as HOMA-IR compared to the control subjects (Table 3). We observed no significant difference in BMI, age, and body fat between the mentioned groups. Additionally, the individuals taking statins had significantly lower plasma concentrations of LDL- and total cholesterol compared to the control group, as expected.

Table 3. Anthropometric and fasting biochemical characteristics of healthy subjects (Control) and statin patients (Statins) involved in the study.

\begin{tabular}{cccc}
\hline Variable & Control & Statins & $p$-Value \\
\hline$n$ & 144 & 51 & \\
$\mathrm{M} / \mathrm{F}$ & $49 / 95$ & $18 / 33$ & \\
Age & $59.0 \pm 10.5$ & $62.2 \pm 7.7$ & 0.1094 \\
BMI & $30.4 \pm 6.1$ & $30.5 \pm 5.6$ & 0.8208 \\
Body fat, $\%$ & $38.5 \pm 10.1$ & $38.9 \pm 9.0$ & 0.9573 \\
Glucose, $\mathrm{mmol} / \mathrm{L}$ & $6.3 \pm 1.3$ & $7.2 \pm 1.7$ & $<0.001$ \\
HbA1C, $\mathrm{mmol} / \mathrm{mol}$ & $38.4 \pm 8.0$ & $44.5 \pm 11.3$ & $<0.001$ \\
Insulin, $\mathrm{mmol} / \mathrm{L}$ & $11.4 \pm 7.9$ & $15.4 \pm 11.8$ & 0.0250 \\
HOMA-IR, mmol $\times \mu \mathrm{U} / \mathrm{L}^{2}$ & $3.1 \pm 2.3$ & $4.9 \pm 4.1$ & 0.0021 \\
Cholesterol, $\mathrm{mmol} / \mathrm{L}$ & $4.6 \pm 2.0$ & $4.1 \pm 1.5$ & 0.0060 \\
HDL cholesterol, mmol/L & $1.9 \pm 1.0$ & $1.5 \pm 0.6$ & 0.0162 \\
LDL cholesterol, $\mathrm{mmol} / \mathrm{L}$ & $3.4 \pm 0.9$ & $2.6 \pm 0.7$ & $<0.001$ \\
Triglycerides, $\mathrm{mmol} / \mathrm{L}$ & $1.3 \pm 0.6$ & $1.6 \pm 0.8$ & 0.0113
\end{tabular}

Statistical analysis was performed with a non-parametric Mann-Whitney test for unpaired samples. $n$-number; HbA1c_-glycosylated haemoglobin; HOMA-IR-homeostatic model assessment of insulin resistance, HDL-high-density lipoprotein; LDL-low-density lipoprotein. The data are shown as mean \pm SD.

After adjustment for age, sex, BMI, HbA1c levels, LDL cholesterol, and diagnosis of diabetes or prediabetes, we found that statin treatment explained $16.8 \%$ of the variability in HOMA-IR (model $\mathrm{r}^{2}=0.4969, p<0.01$ ) compared to controls (Table 4).

Table 4. Linear regression analysis for estimating the impact of statin treatment and LDL-cholesterol on HOMA-IR. All continuous variables and the outcome were log-transformed.

\begin{tabular}{ccc}
\hline Variable & Std. $\beta$ & $p$-Value \\
\hline Statin & 0.168 & 0.006 \\
BMI & 0.415 & 0.000 \\
HbA1c & 0.215 & 0.014 \\
Age & -0.031 & 0.605 \\
Sex & -0.119 & 0.030 \\
Diabetes & 0.233 & 0.008 \\
LDL cholesterol & 0.154 & 0.008 \\
\hline
\end{tabular}

HbA1c—glycosylated haemoglobin; LDL-low-density lipoprotein.

Having observed that pharmacological inhibition of HMG-CoA reductase with statins was associated with insulin resistance, we aimed to dissect the potential underlying mechanisms and studied the direct effects of simvastatin and its active metabolite on adipose tissue and pancreatic $\beta$-cell functions in vitro. 


\subsection{In Vitro Studies}

2.3.1. Effects of Simvastatin on Adipocyte Glucose Uptake and Lipolysis

To understand whether statin-associated insulin resistance is relevant to direct effects on adipose tissue, we studied the effects of simvastatin and its active metabolite on human adipocyte glucose and lipid metabolism and differentiation. Incubation of adipose tissue with simvastatin and its active metabolite, simvastatin hydroxy acid, for $24 \mathrm{~h}$ has demonstrated no significant effect of therapeutic concentration of the drugs on adipocyte glucose uptake, while the supra-therapeutic concentrations inhibited insulin-stimulated glucose uptake by approximately $10 \%(p<0.05)$ (Figure $2 \mathrm{~A})$. The viability assay indicated no significant effect of simvastatin and its active metabolite on the viability of adipocytes (data not shown). Dexamethasone was used as a positive control and significantly reduced glucose uptake in adipocytes after $24 \mathrm{~h}$, as expected. Short-term (30 min) incubation of adipocytes with simvastatin did not affect glucose uptake (data not shown).

(A)

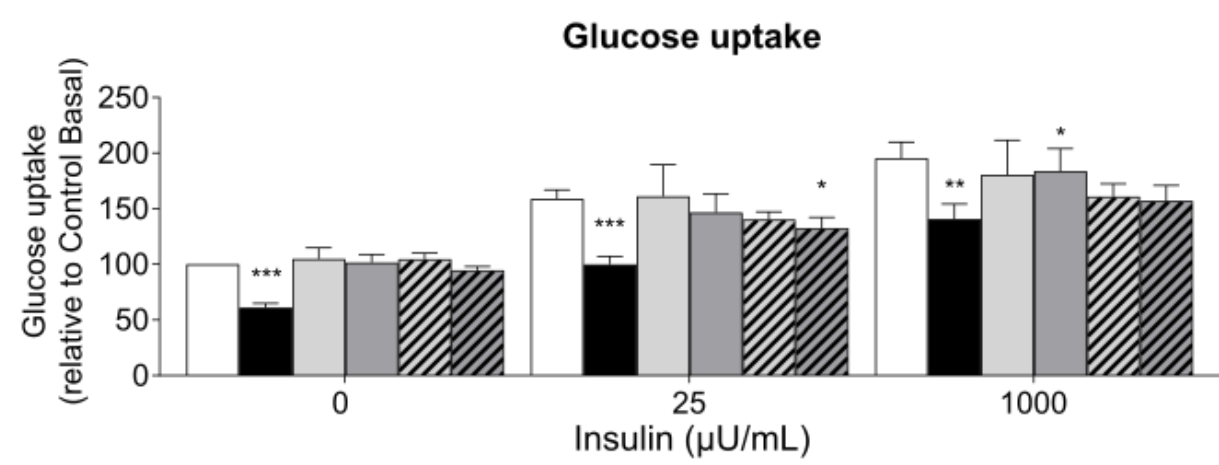

(B)

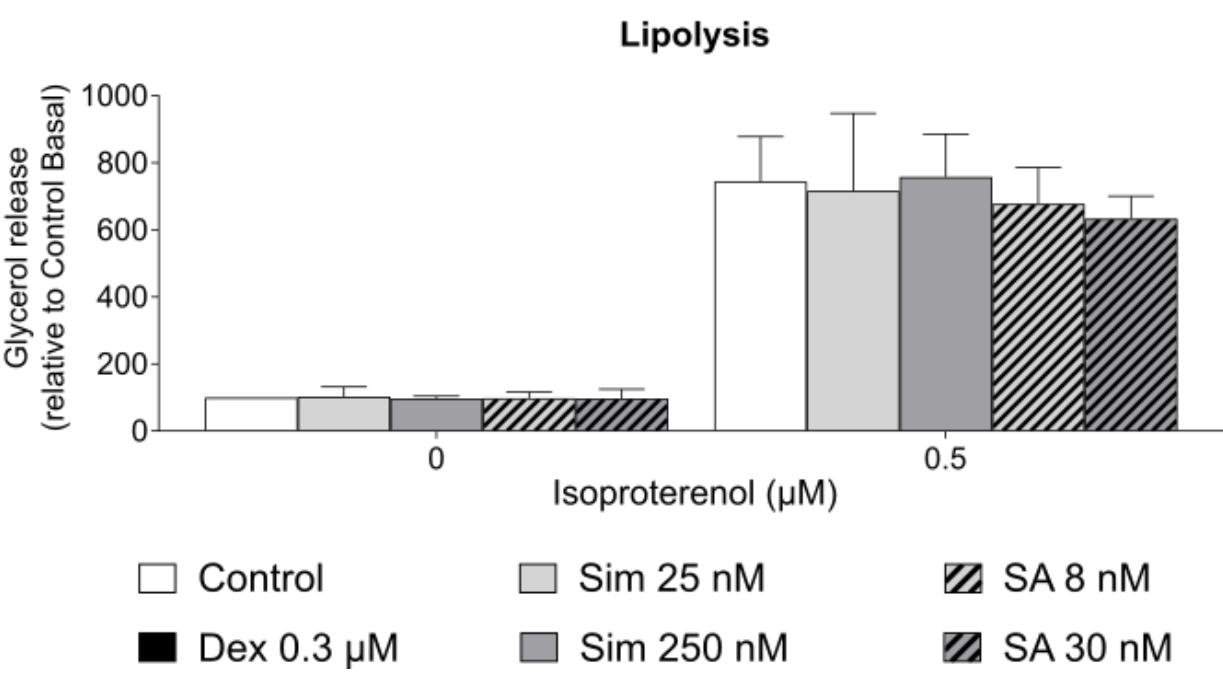

Figure 2. (A) Effects of simvastatin and its active metabolite on adipocyte glucose uptake. The graph depicts 14C-glucose uptake by mature human adipocytes isolated from adipose tissue pre-incubated with the given concentrations of simvastatin $(n=5-7)$ and simvastatin hydroxy acid $(n=5)$ for $24 \mathrm{~h}$ at basal $(0 \mu \mathrm{U} / \mathrm{mL})$, submaximal $(25 \mu \mathrm{U} / \mathrm{mL})$, and maximal $(1000$ $\mu \mathrm{U} / \mathrm{mL}$ ) insulin concentrations. Dexamethasone (Dex, $0.3 \mu \mathrm{M})$ - positive control $(n=14)$. (B) Effects of simvastatin and its active metabolite on adipocyte lipolysis. The graph shows basal and isoproterenol-stimulated lipolysis measured by glycerol release by mature human adipocytes isolated from adipose tissue pre-incubated with the given concentrations of simvastatin $(n=4)$ and simvastatin hydroxy acid $(n=3)$ for 24 h. Graph shows mean \pm S.E.M. ${ }^{*} p<0.05,{ }^{* *} p<0.01$, and *** $p<0.001$, relative to Control. 
In addition, simvastatin and simvastatin hydroxy acid had no significant effect on the adipocyte lipolysis after $24 \mathrm{~h}$ incubation of the adipose tissue with therapeutic and supra-therapeutic concentrations of the drugs (Figure 2B).

2.3.2. Effects of Simvastatin and Its Active Metabolite on Adipose Tissue Gene Expression

Treatment of adipose tissue with simvastatin and simvastatin hydroxy acid did not affect the mRNA expression of adipokines-adiponectin and leptin, and the proinflammatory genes, IL6 and IL18. Therapeutic concentrations of simvastatin and simvastatin hydroxy acid increased mRNA expression of TFAM by $30(p<0.05)$ and $20 \%$, respectively, but did not affect PPARGC1A expression (Table 5). Simvastatin (both 25 and $100 \mathrm{nM})$ nominally increased IL1B ( 30-40\%).

Table 5. Fold-change in gene expression in adipose tissue after $24 \mathrm{~h}$ incubation with simvastatin (Sim) and simvastatin acid (SA).

\begin{tabular}{|c|c|c|c|c|c|}
\hline \multirow{2}{*}{$\begin{array}{c}\text { Gene } \\
\text { Symbol }\end{array}$} & $\operatorname{Sim} 25 \mathrm{nM}$ & Sim $100 \mathrm{nM}$ & SA $8 \mathrm{nM}$ & SA $30 \mathrm{nM}$ & Dex $0.3 \mu \mathrm{M}$ \\
\hline & Fold Change & Fold Change & Fold Change & Fold Change & Fold Change \\
\hline \multicolumn{6}{|c|}{ Adipokines } \\
\hline$A D I P O Q$ & $1.11 \pm 0.07$ & $1.08 \pm 0.13$ & $1.12 \pm 0.13$ & $1.02 \pm 0.11$ & $0.91 \pm 0.06$ \\
\hline LEP & $1.02 \pm 0.05$ & $1.01 \pm 0.07$ & $1.18 \pm 0.15$ & $0.97 \pm 0.08$ & $1.64 \pm 0.39$ \\
\hline \multicolumn{6}{|c|}{ Pro-inflammatory cytokines } \\
\hline IL6 & $1.10 \pm 0.20$ & $1.22 \pm 0.22$ & $1.37 \pm 0.24$ & $1.05 \pm 0.16$ & $0.20 \pm 0.04 *$ \\
\hline IL1B & $1.31 \pm 0.23$ & $1.42 \pm 0.19$ & $1.19 \pm 0.14$ & $1.15 \pm 0.14$ & $0.14 \pm 0.05 *$ \\
\hline IL18 & $1.03 \pm 0.07$ & $1.01 \pm 0.06$ & $1.03 \pm 0.09$ & $1.00 \pm 0.09$ & $3.23 \pm 0.54 *$ \\
\hline \multicolumn{6}{|c|}{ Regulation of mitochondrial function } \\
\hline PPARGC1A & $1.08 \pm 0.17$ & $0.84 \pm 0.11$ & $1.12 \pm 0.20$ & $1.13 \pm 0.19$ & $2.82 \pm 0.29 *$ \\
\hline TFAM & $1.30 \pm 0.12 *$ & $1.03 \pm 0.07$ & $1.20 \pm 0.10$ & $1.09 \pm 0.09$ & $0.94 \pm 0.05$ \\
\hline \multicolumn{6}{|c|}{ Plasma membrane proteins } \\
\hline SLC2A4 & $0.91 \pm 0.06$ & $0.94 \pm 0.09$ & $0.95 \pm 0.08$ & $0.84 \pm 0.05$ & $0.57 \pm 0.10 *$ \\
\hline$C A V 1$ & $1.15 \pm 0.11$ & $1.15 \pm 0.10$ & $1.10 \pm 0.12$ & $0.96 \pm 0.10$ & $1.35 \pm 0.15$ \\
\hline \multicolumn{6}{|c|}{$\begin{array}{l}\text { ADIPOQ-Adiponectin, LEP-Leptin, IL6-Interleukin } 6, \text { IL1B-Interleukin } 1 \beta, \text { IL18 - Interleukin 18, } \\
P P A R G C 1 A \text {-Peroxisome proliferator-activated receptor gamma coactivator 1-alpha, TFAM-Mitochondrial } \\
\text { transcription factor A, SLC2A4-Glucose transporter type 4,CAV1-Caveolin 1. Human subcutaneous adipose } \\
\text { tissue was incubated without (control) or with Sim or SA. Dexamethasone (Dex)-positive control. Gene ex- } \\
\text { pression was normalized to the expression of the housekeeping gene } 18 S \text {. Relative expression was calculated as } \\
2^{-\triangle \triangle C t} \text {. Results are shown as mean } \pm S E M \text { of } n=9 \text { independent experiments. }{ }^{*} p<0.05 \text {, relative to control. }\end{array}$} \\
\hline
\end{tabular}

\subsubsection{Effects of Simvastatin on Adipogenesis}

Treatment of human SGBS cells with simvastatin and its active metabolite during the course of cell differentiation did not affect adipocyte differentiation rate (Figure 3A,B).

We also measured the gene expression of the master regulator of adipogenesis, peroxisome proliferator-activated receptor gamma (PPARG) (Figure 3C). The expression of the gene followed the expected trend increasing over the course of adipocyte differentiation in all the conditions. The data showed that statin treatment during the differentiation did not affect the mRNA expression of PPARG (Figure 3C).

We also observed that $\operatorname{Sim} 100 \mathrm{nM}$ and both concentrations of SA reduced the expression of SLC2A4 (GLUT4) mRNA by $30 \%(p<0.05)$ and $25 \%(n s)$, respectively (Table 6 ) on day 7 of differentiation. However, this effect disappeared on day 14 of adipocyte differentiation. Similarly, we did not observe any significant change in GLUT4 protein expression in adipocytes after 14 days of differentiation (Figure 3D, E). Sim $100 \mathrm{nM}$ and SA $30 \mathrm{nM}$ reduced the expression of $L E P$ and $A D I P O Q$ nominally at days 7 and 14 of differentiation. 
(A)
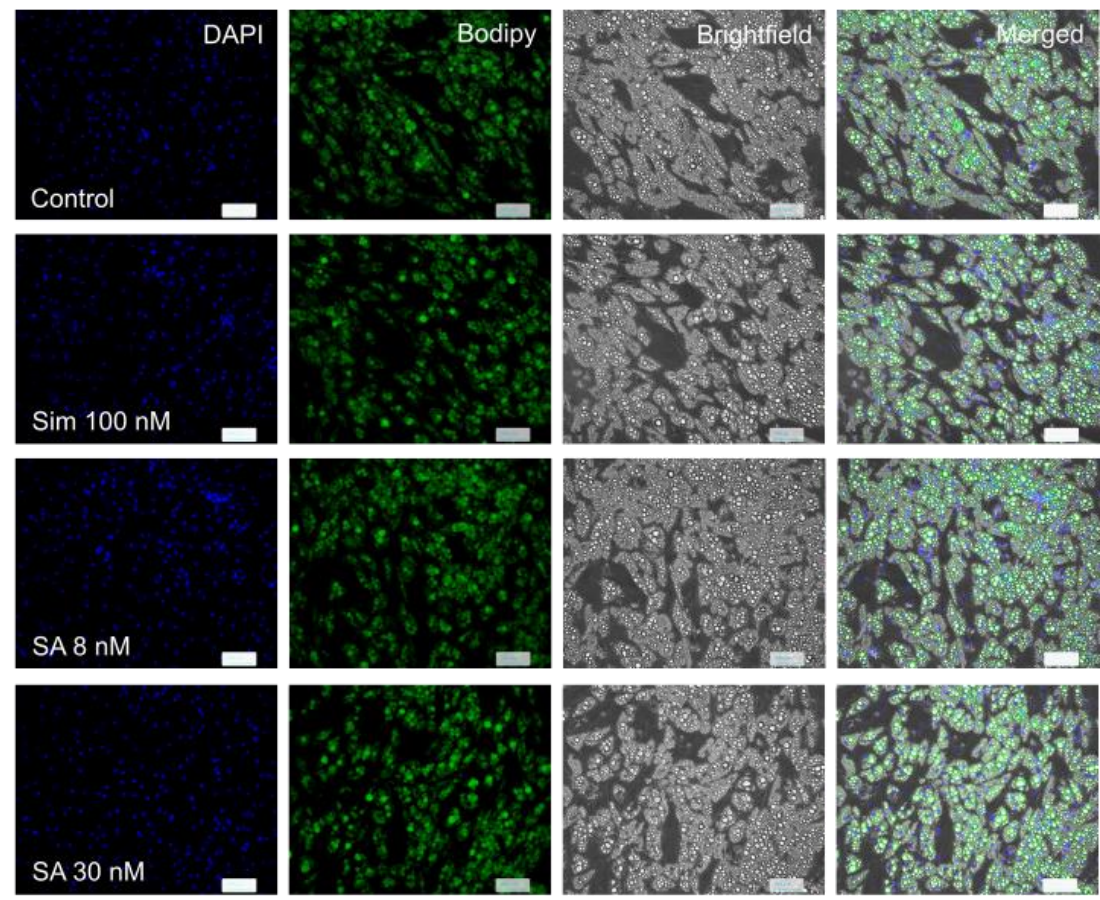

(B)

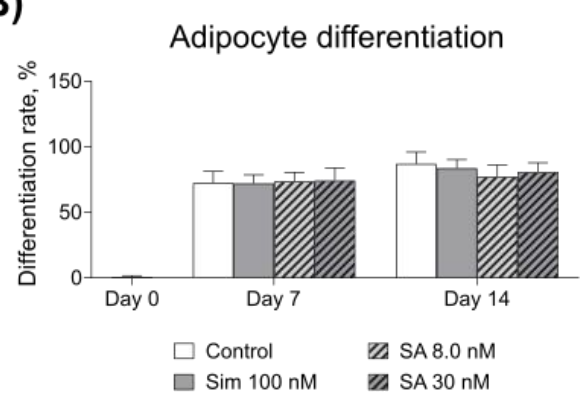

(C)
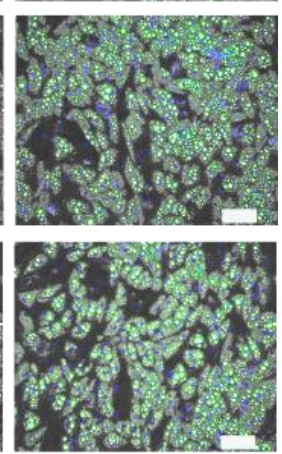

(D)
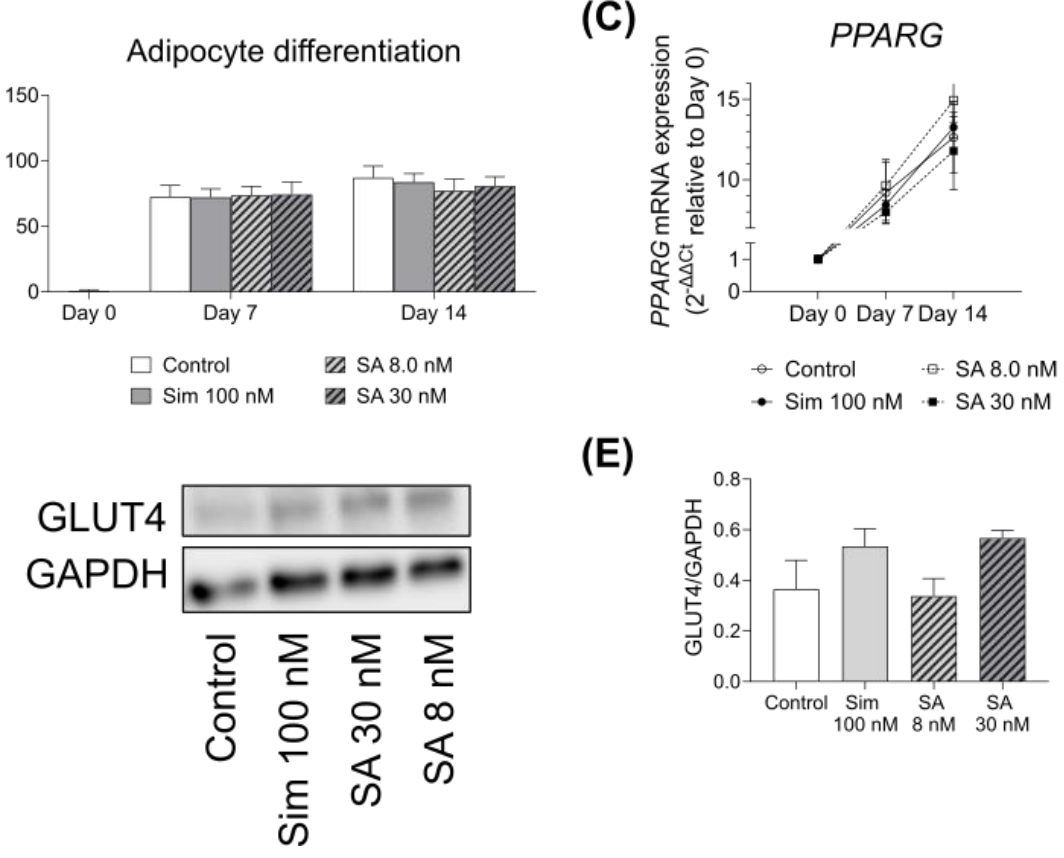

(E)

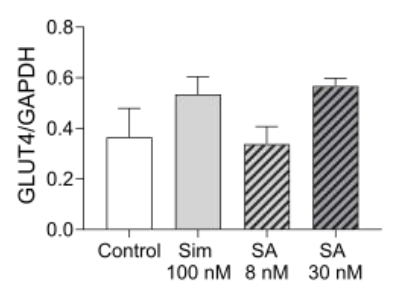

Figure 3. Effects of simvastatin and simvastatin acid on adipocyte differentiation. (A) Representative images of differentiation rate of adipocytes treated without (Control) or with Simvastatin $100 \mathrm{nM}$ (Sim $100 \mathrm{nM}$ ), simvastatin hydroxy acid 8 and $30 \mathrm{nM}$ (SA $8 \mathrm{nM}$ and SA $30 \mathrm{nM}$, respectively). Left to right: Nuclei are shown in blue (DAPI), lipid droplets are shown in green (Bodipy), brightfield image, and merged. (B) Quantification of adipocyte differentiation rate. (C) The differentiation rate was also assessed by measuring the mRNA expression of the master regulator of adipogenesis PPARG. GUSB was used as the housekeeping gene. Relative gene expression was measured as $2^{-\triangle \Delta C t}$. (D) Representative blot of GLUT4 expression in adipocytes treated without (Control) or with Simvastatin $100 \mathrm{nM}$ (Sim $100 \mathrm{nM}$ ), simvastatin hydroxy acid $30 \mathrm{nM}$ and $8.0 \mathrm{nM}$ (SA $30 \mathrm{nM}$ and SA $8 \mathrm{nM}$ ), respectively, at day 14. (E) Quantification of GLUT4 expression. Graphs show mean \pm S.E.M. of $n=3$ independent experiments. 
Table 6. Fold change in gene expression in SGBS adipocytes differentiated in the absence or presence simvastatin (Sim) and simvastatin acid (SA).

\begin{tabular}{|c|c|c|c|c|c|c|}
\hline \multicolumn{7}{|c|}{ Differentiation Day } \\
\hline & \multicolumn{3}{|c|}{ Day 7} & \multicolumn{3}{|c|}{ Day 14} \\
\hline Gene symbol & Sim $100 \mathrm{nM}$ & SA $8 \mathrm{nM}$ & SA $30 \mathrm{nM}$ & Sim $100 \mathrm{nM}$ & SA $8 \mathrm{nM}$ & SA $30 \mathrm{nM}$ \\
\hline \multicolumn{7}{|c|}{ Regulation of Adipogenesis } \\
\hline PPARG & $0.94 \pm 0.12$ & $1.05 \pm 0.03$ & $0.89 \pm 0.08$ & $1.07 \pm 0.09$ & $1.20 \pm 0.09$ & $0.93 \pm 0.05$ \\
\hline \multicolumn{7}{|c|}{ Adipokines } \\
\hline ADIPOQ & $\begin{array}{c}0.45 \pm 0.08 \\
(p=0.058)\end{array}$ & $0.93 \pm 0.03$ & $0.66 \pm 0.12$ & $\begin{array}{c}0.66 \pm 0.06 \\
(p=0.054)\end{array}$ & $0.93 \pm 0.38$ & $\begin{array}{c}0.41 \pm 0.11 \\
(p=0.054)\end{array}$ \\
\hline$L E P$ & $0.92 \pm 0.08$ & $0.89 \pm 0.06$ & $0.84 \pm 0.05$ & $0.79 \pm 0.07$ & $0.80 \pm 0.03$ & $1.19 \pm 0.06$ \\
\hline \multicolumn{7}{|c|}{ Regulation of Miochondrial Function } \\
\hline PPARGC1A & $0.81 \pm 0.12$ & $\begin{array}{c}0.78 \pm 0.04 \\
(p=0.06)\end{array}$ & $\begin{array}{c}0.71 \pm 0.06 \\
(p=0.06)\end{array}$ & $1.03 \pm 0.09$ & $1.07 \pm 0.26$ & $1.01 \pm 0.12$ \\
\hline PDK4 & $0.95 \pm 0.12$ & $1.02 \pm 0.02$ & $1.06 \pm 0.22$ & $1.17 \pm 0.06$ & $1.04 \pm 0.10$ & $0.93 \pm 0.03$ \\
\hline TFAM & $0.94 \pm 0.05$ & $1.12 \pm 0.01 * *$ & $0.95 \pm 0.06$ & $0.96 \pm 0.15$ & $0.97 \pm 0.10$ & $0.86 \pm 0.16$ \\
\hline \multicolumn{7}{|c|}{ Plasma Membrane Proteins } \\
\hline SLC2A4 & $0.62 \pm 0.04$ * & $0.76 \pm 0.09$ & $0.76 \pm 0.11$ & $0.79 \pm 0.16$ & $0.79 \pm 0.10$ & $1.06 \pm 0.07$ \\
\hline
\end{tabular}

PPARG-Peroxisome proliferator-activated receptor gamma, ADIPOQ-Adiponectin, LEP-Leptin, PPARGC1A—Peroxisome proliferatoractivated receptor gamma coactivator 1-alpha, PDK4-Pyruvate dehydrogenase kinase 4, TFAM-Mitochondrial transcription factor A, SLC2A4-Glucose transporter type 4. Human SGBS adipocytes were differentiated without (control) or with Sim or SA. Gene expression was normalized to the expression of the housekeeping gene GUSB. Relative expression was calculated as $2^{-\Delta \Delta C t}$ relative to respective control. Results are shown as mean \pm SEM of $n=3$ independent experiments. ${ }^{*} p<0.05,{ }^{* *} p<0.01$.

Since simvastatin has been shown to induce mitochondrial dysfunction, we also tested its effects on the expression of genes involved in the regulation of mitochondrial function, namely, PPARGC1A, PDK4, and TFAM. We observed no significant effect of the drugs on these genes after 14 days of treatment.

\subsubsection{Effects of Simvastatin on $\beta$-Cell Function}

Human islets were cultured for 2 days in the presence or absence of $0.5 \mathrm{mM}$ palmitate with or without simvastatin 20 and $100 \mathrm{nM}$. After culture, dynamic insulin secretion was measured by perifusing islets in low $(5.5 \mathrm{mM})$ and high $(11 \mathrm{mM})$ glucose. Islets treated with palmitate alone for $48 \mathrm{~h}$ showed an approximately 2-fold increase in glucose-stimulated insulin secretion (GSIS) compared to control at $11 \mathrm{mM}$ glucose (Figure $4 \mathrm{~A}, \mathrm{~B})(p<0.05)$. At $20 \mathrm{nM}$, simvastatin did not affect palmitate-induced insulin hypersecretion (Figure 4B); however, simvastatin $100 \mathrm{nM}$ reduced insulin hypersecretion $(p<0.05)$, compared to palmitate treatment. 
(A)
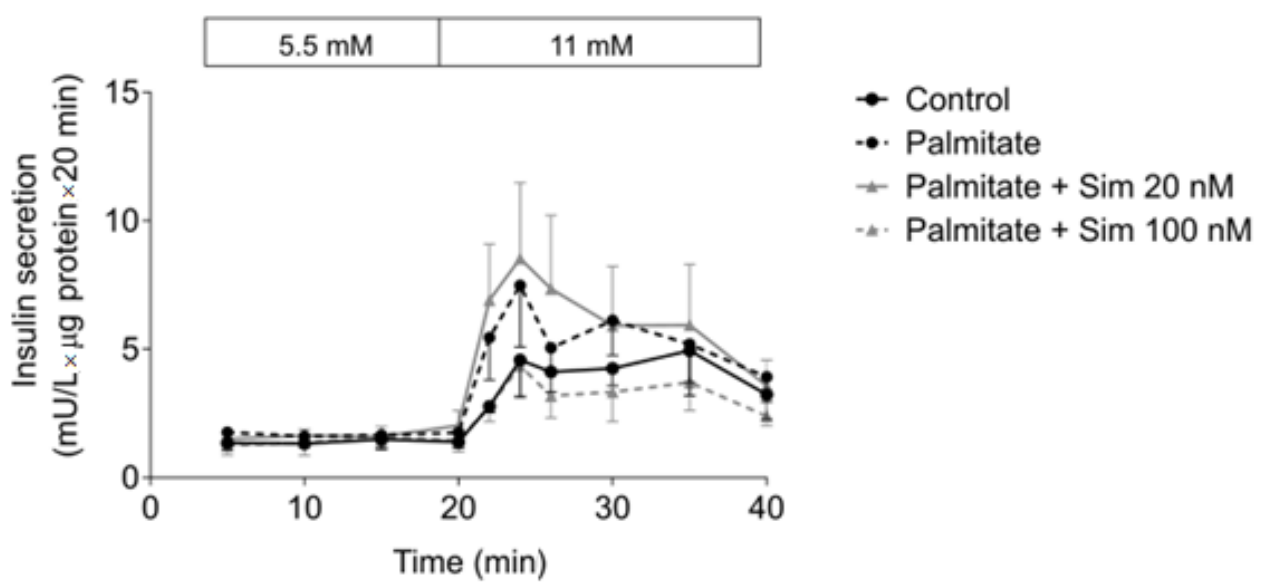

(B)

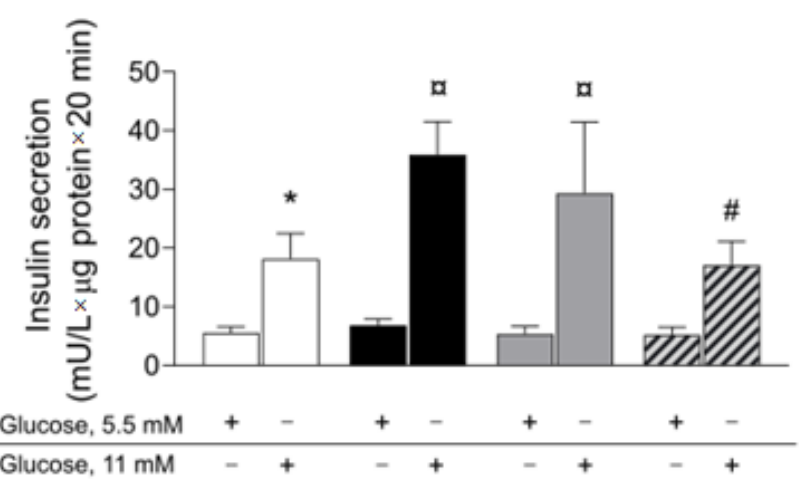

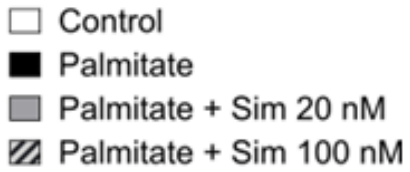

Figure 4. (A) Glucose-stimulated insulin secretion from perifused human islets exposed to palmitate (black dashed line), the combination palmitate and simvastatin $20 \mathrm{nM}$ (grey line), the combination palmitate and simvastatin $100 \mathrm{nM}$ (grey dashed line) or in the absence of compounds, control, (black line) for $48 \mathrm{~h}$. Insulin secretion was measured at 5.5 and 11 $\mathrm{mmol} / \mathrm{L}$ glucose, $20 \mathrm{~min}$ each, and normalized to protein. (B) AUC insulin secretion for 5.5 and $11 \mathrm{mmol} / \mathrm{L}$ glucose was calculated from panel A. Data are shown as mean \pm SEM for 4 independent experiments (with 4 different human islet preparations). ${ }^{*} p<0.05$ compared to control $5.5 \mathrm{mM}$, a $p<0.05$ compared to control $11 \mathrm{mM}$, and \# $p<0.05$ compared to palmitate $11 \mathrm{mM}$ alone (black bar).

\section{Discussion}

In this study, we observed that impaired HMG-CoA reductase activity caused by statin exposure or genetic variants are associated with diabetes and diabetes-related traits. We discovered that HMGCR expression is associated with several adipose tissue metabolic pathways, including insulin signaling and citrate cycle, and increased blood circulating levels of phosphatidylcholines and sphingomyelins, as well as insulin resistance. This led us to hypothesize that there might be direct effects of statins on adipose tissue metabolism or $\beta$-cell function. Direct treatment of human adipose tissue or $\beta$-cells ex vivo modestly reduced adipocyte glucose uptake and $\beta$-cell insulin secretion, albeit at supra-therapeutic concentrations.

Our analysis indicated the involvement of HMGCR in a number of metabolic pathways in the adipose tissue. Among these, the most relevant to adipose tissue metabolism include insulin signaling and insulin resistance. Our data showed a positive association of HMGCR with insulin signaling pathway, particularly, PI3K signaling, and negative association with NF-KB signaling, which suggests that reduced activity of HMGCR could contribute to 
insulin resistance. A recent study in mice demonstrated that adipose tissue-specific deletion of HMGCR resulted in lipodystrophy and severe glucose intolerance and insulin resistance in the animals [22]. We also observed that HMGCR expression in the adipose tissue was also associated with several mitochondrial pathways, including oxidative phosphorylation, citrate cycle, and thermogenesis. Balaz and colleagues have reported the importance of the mevalonate pathway in adipocyte browning and thermogenesis [21]. Furthermore, metabolic side effects of statins were linked to their ability to directly induce mitochondrial dysfunction as well as depletion of mevalonate pathway metabolites [27]. We observed that HMGCR expression in the adipose tissue did not differ between healthy individuals and T2D patients. However, the expression of the gene does not represent the activity of the enzyme, therefore, more detailed studies on HMG-CoA reductase are warranted. We compared the expression of HMGCR in 31 statin-free individuals with HMGCR expression in nine patients taking statins was significantly higher than in the adipose tissue of statinfree subjects. Statin therapy has been shown to induce compensatory upregulation in the expression and activity of HMG-CoA reductase in the liver in animal and human studies $[28,29]$. It appears that statins have similar effects in human adipose tissue as well. However, these results need to be interpreted with caution as the number of subjects in the two groups was limited and not balanced.

The T allele of the HMGCR polymorphism rs12916 is associated with reduced hepatic HMGCR expression and reduced LDL-cholesterol levels [15]. We studied the association of this polymorphism with plasma metabolites and observed a strong negative correlation of the SNP with plasma sphingomyelins and phosphatidylcholines. The plasma concentrations of phosphatidylcholines and sphingomyelins were reduced in subjects with impaired HMG-CoA reductase activity. Reduced HMG-CoA reductase activity leads to diminished conversion of HMG-CoA to mevalonate [1]. Mevalonate has been reported to increase sphingomyelin levels via inhibiting acid sphingomyelinase activity [30], and therefore reduced sphingomyelin levels in subjects with reduced HMG-CoA reductase activity would have been expected. Inhibition of the HMG-CoA reductase has been shown to inhibit de novo synthesis of phosphatidylcholines via the cytidine diphosphate-choline pathway, which, in turn, could reduce its plasma lipid levels [31]. Although most clinical studies suggested that sphingomyelins and phosphatidylcholines, such as C32:2, C34:1, and C34:2, are associated with reduced insulin sensitivity in humans [32,33], a metabolomic analysis in newly developed type 2 diabetes subjects shows that some phosphatidylcholines, are significantly associated with decreased risk of diabetes [33,34]. Interestingly, we observed a negative association of reduced HMGCR activity with plasma sphingomyelins and phosphatidylcholines, suggesting that any disruption of phospholipid metabolism could affect metabolism. However, whether changes in phospholipids are a cause or consequence of insulin resistance requires further investigation.

Since pharmacological inhibition of HMG-CoA reductase with statins is associated with new-onset diabetes in patients, we compared insulin resistance between subjects taking statins and age- and BMI-matched control subjects. We tested the effect of statin treatment on systemic glucose tolerance in another independent cohort of 195 individuals, to verify whether the diabetogenic effect of statins might be due to pathophysiological mechanisms occurring in other tissues. After adjusting for multiple confounders, including BMI, age, sex, diabetes status, HbA1c, and LDL cholesterol levels, statins use was associated with an increased HOMA-IR. Similarly, diabetogenic effects of statins have been reported in patients previously $[6,8,35]$.

Since statin therapy was associated with increased systemic insulin resistance, we hypothesized that the diabetogenic effects of statin treatment could be mediated via a direct effect on adipose tissue and $\beta$-cell function. We observed that the drug or its active metabolite led to a $10 \%$ reduction in insulin-stimulated adipocyte glucose uptake only at the supra-therapeutic concentrations. Our data are consistent with the study on 3T3-L1 adipocytes treated with $100 \mathrm{ng} / \mathrm{mL}$ of simvastatin (ca $230 \mathrm{nM}$ ), which slightly reduce adipocyte glucose uptake [23]. To the best of our knowledge, the effects of simvastatin 
hydroxy acid on adipocyte glucose uptake have not been previously studied. A similar trend in glucose uptake regulation was expected, as both drugs target the same enzyme. However, adipose tissue accounts for less than $10 \%$ of the whole-body glucose uptake [35]. Therefore, the modest $10 \%$ reduction of the adipocyte glucose uptake is unlikely to lead to an increased risk of type 2 diabetes, as observed in patients taking statins. Neither simvastatin nor its active metabolite altered adipocyte lipolysis after $24 \mathrm{~h}$ incubation of the adipose tissue. Our data are in accordance with the study conducted by Henriksbo and colleagues, who reported no effects of atorvastatin on 3T3-L1 adipocyte lipolysis and glucose uptake [35].

The presence of simvastatin and its active metabolite during the adipogenesis of SGBS cells did not alter their differentiation rate. Similar to our findings, Nakata and colleagues did not observe any changes in murine 3T3-L1 adipocyte maturation with simvastatin [23]. We did not observe any significant effect on adipocyte GLUT4 expression after 14 days of differentiation at both mRNA and protein levels, while Nakata and co-workers reported that simvastatin reduced GLUT4 expression in 3T3-L1 cells after 10 days of culture [23]. The discrepancy in our data could be due to the differences in the experimental setup, such as different cell lines or concentration differences, as Nakata and colleagues used a much higher concentration of the drug than in our setting.

We observed no significant effect of simvastatin and its active metabolite, SA, on the mRNA expression of adipokines in the adipose tissue. It has been shown that gene expression of adiponectin was not altered in the adipose tissue of animals treated with simvastatin for 2 weeks, while leptin mRNA expression was increased by the statins [36]. Maeda and Horiuchi reported a reduction in the expression of leptin mRNA in 3T3-L1 adipocytes differentiated in the presence of simvastatin [24]. Our data similarly showed a nominal reduction in $L E P$ and $A D I P O Q$ expression in SGBS cells. Similarly, reduced serum adiponectin concentration was reported in patients treated with simvastatin for 2 months [37].

Simvastatin treatment nominally increased the expression of IL1B in the adipose tissue. Our data are in accordance with the study by Henriksbo and colleagues, who reported that statins, including simvastatin, induce IL1 $\beta$ secretion via NLRP3 inflammasome activation in macrophages, which are the dominant leukocyte type in the adipose tissue [38,39]. Although statins have been reported to have anti-inflammatory effects by reducing circulating C-reactive protein and pro-inflammatory cytokines, they appear to induce adipose tissue inflammation. Interestingly, our data did not show any significant effect of simvastatin on the genes involved in the regulation of mitochondrial functions, namely PPARGC1A, TFAM, and PDK4. We also did not observe any changes in CAV1 expression, which could be used as a marker of cholesterol depletion in adipose tissue [36]. This could be due to a relatively short-term incubation of adipose tissue and adipocytes with the drugs, while the patients taking statins are exposed to the drug for a much longer period. Additionally, the majority of in vitro studies use high concentrations of the drug [25], while we selected the concentrations relevant to the plasma levels of the drugs.

Although our study demonstrated no direct effects of simvastatin and its active metabolite on adipose tissue metabolism, genetic or pharmacological inhibition of HMGCoA reductase has been associated with weight gain, which itself is a risk factor for the development of diabetes $[15,40]$ therefore, increased adiposity could be one of the contributors to diabetogenic effects of statins.

Similar to adipose tissue, we did not observe a significant effect of therapeutic concentration of simvastatin on the human pancreatic islets. When we increased the simvastatin concentration, the statin normalized palmitate-induced insulin hypersecretion, which has been suggested as a treatment strategy for early obesity intervention [41]. In human islets exposed to a high statin concentration alone, GSIS was reduced [42]. Thus, to what extent the observed positive effect of the higher statin concentration in $\beta$-cells of the palmitate-treated islets in the present study could be of clinical use remains to be decided. Statin-induced reduction in insulin secretion from $\beta$-cells happens because 
statins disrupt the production of endogenous cholesterol in $\beta$-cells, which is important to maintain the functionality of $\mathrm{CaV}$ channels and insulin secretion [17]. Additionally, pancreatic $\beta$-cell-specific ablation of HMGCR gene in mice resulted in a phenotype with severe hypoinsulinemia and hyperglycemia [43]. This study revealed the importance of HMGCR and mevalonate pathway for pancreatic $\beta$-cell development [43].

Our study has several limitations. One of the limitations is the short incubation time compared to the duration of the treatment in the patients. HMG-CoA reductase is highly important for adipose tissue and pancreas functions [22,43]. Although $24 \mathrm{~h}$ incubation of MIN6 cells with atorvastatin $(10 \mu \mathrm{M})$ has shown a reduction in cholesterol content in the cells [44], measuring the cholesterol content or HMGCR activity in human islets and adipose tissue is warranted. Unfortunately, it was not possible in our setting due to the limited amount of material and reduction in the number of donors because of the COVID19 pandemic. To our best knowledge, there are no reports on the pancreatic $\beta$-cell function in individuals with rs12916 T-allele, which would be an important asset to understanding the role of HMG-CoA reductase in islet function. Additionally, glucose-stimulated insulin secretion in the human islets is also warranted, as we only measured GSIS after treatment of pancreatic islets with palmitate, which is a diabetogenic condition [45]. Another limitation is a small sample size for both adipose tissue and pancreatic islet donors. Finally, for the observational study results, although we tried to adjust for several confounding factors, these data need to be interpreted with caution as the observational study performed in this work had a selection bias since we can assume that patients on statin treatment display a less favorable metabolic profile and are more prone to develop metabolic syndrome. In addition, it should be noted that there could be more parameters to consider, such as treatment duration, the dose of the medication, as well as the age of the patients since high doses of statins, older age, and female sex were associated with a higher risk of new-onset diabetes $[8,46,47]$.

Our study targeted the effects of statins on human cells and tissues. Our data show that genetic inhibition of HMG-CoA reductase is negatively correlated with plasma sphingomyelins and phosphatidylcholines, which appear to play a role in insulin resistance development. Our results suggest that HMGCR expression and activity in adipose tissue are associated with metabolic pathways; however, statin treatment has a minor direct effect on adipose tissue metabolism and $\beta$-cell insulin secretion. Other tissues, such as liver or skeletal muscle, might be of greater interest when investigating the diabetogenic effects of statins.

\section{Materials and Methods}

\subsection{Subjects and Adipose Tissue Biopsies}

Overall, we included 216 individuals of whom 51 were on statin treatment (33-simvastatin; 17-atorvastatin; 1 -rosuvastatin) into the study. Subjects fasted overnight ( $>10 \mathrm{~h})$, and fasting venous samples were collected for biochemical analysis of glucose, insulin, $\mathrm{HbA1c}$, and lipids at the Department of Clinical Chemistry, Uppsala University Hospital. Anthropometric characteristics, fasting blood biochemical values, and T2D status of the subjects are shown in Table 7. Additionally, pancreatic islets were collected from 4 brain-dead non-diabetic donors (3M/1F, Age: 19-27, BMI: $19.7-27.5 \mathrm{~kg} / \mathrm{m}^{2}$ ). 
Table 7. Biochemical and anthropometric characteristics of the subjects.

\begin{tabular}{cc}
\hline Variable & Mean \pm SD \\
\hline$n$ & 216 \\
Sex (male/female), $n$ & $73 / 143$ \\
Diabetes status (Healthy/T2D/Prediabetes), $n$ & $153 / 47 / 16$ \\
Age (years) & $57 \pm 14$ \\
BMI (kg/m ${ }^{2}$ ) & $30.1 \pm 5.9$ \\
Waist/hip ratio & $0.9 \pm 0.1$ \\
Systolic blood pressure (mmHg) & $135.7 \pm 17.5$ \\
Diastolic blood pressure (mmHg) & $76.5 \pm 10.9$ \\
Body fat (\%) & $38.2 \pm 9.7$ \\
Plasma glucose (mmol/L) & $6.4 \pm 1.4$ \\
HbA1C (mmol/mol) & $39.3 \pm 9.2$ \\
Serum insulin (mU/L) & $12.1 \pm 8.9$ \\
HOMA-IR (mmol $\times$ mU/L $/ 2)$ & $3.4 \pm 2.9$ \\
Plasma total cholesterol (mmol/L) & $4.5 \pm 1.8$ \\
Plasma HDL cholesterol (mmol/L) & $1.8 \pm 0.9$ \\
Plasma LDL cholesterol (mmol/L) & $3.2 \pm 0.9$ \\
Plasma triglycerides (mmol/L) & $1.4 \pm 0.7$ \\
\hline
\end{tabular}

Data show mean \pm SD, HbA1c, glycosylated hemoglobin; HOMA-IR, homeostatic model assessment of insulin resistance index (fasting glucose $\times$ fasting insulin/22.5); LDL, low-density lipoprotein; HDL, high-density lipoprotein.

Individuals with type 1 diabetes mellitus and other diseases, such as cancer or endocrine disorders, were excluded. The study was approved by the Swedish Ethical Review Authority in Uppsala (DNR 2013/183-494 and 2018/385), and all participants gave their written informed consent. Ethical permission to use human islets isolated from human donors has been obtained from the Regional Ethical Review Board in Uppsala (EPN number 2010/006).

Needle biopsies were obtained from subcutaneous abdominal adipose tissue from 43 healthy subjects $\left(17 \mathrm{M} / 26 \mathrm{~F}\right.$, Age: $19-72$ yo, BMI: $\left.21.8-38.4 \mathrm{~kg} / \mathrm{m}^{2}\right)$ and 20 individuals with T2D (10M/10F, Age: 41-71, BMI: $\left.22.4-39.9 \mathrm{~kg} / \mathrm{m}^{2}\right)$ with local anesthesia with lidocaine (Xylocain, AstraZeneca, Södertälje, Sweden). The anthropometric and biochemical characteristics of the T2D subjects have been previously reported by Pereira and colleagues [48] Due to the limited amount of adipose tissue obtained, not all experiments were performed in all biopsies. Adipose tissue was used for transcriptomics and metabolomics, and association studies ( $n=31$, see Section 4.2). In addition, adipose tissue was used for in vitro incubation with simvastatin to study the effects on glucose uptake $(n=14)$, lipolysis $(n=7)$, and adipose tissue gene expression $(n=9)$ (see Section 4.4).

Our study consists of three parts, for which the indicated number of subjects was recruited:

\subsection{Association Studies}

Transcriptomics and metabolomics data from 31 statin-free subjects were used to study the association of the gene expression of HMGCR in adipose tissue with other adipose tissue genes and adipose tissue and plasma metabolome. This group also included healthy individuals as well as patients with T2D. The subjects with T2D were on monotherapy with a stable metformin dose (mean metformin dose $500 \mathrm{mg}$ ).

\subsubsection{Association Studies of Adipose Tissue HMGCR Gene Expression}

HMGCR expression in adipose tissue was correlated with other adipose tissue genes and adipose tissue and plasma metabolome of 31 statin-free subjects. This group also included healthy individuals as well as patients with T2D. The analysis was performed using multiple regression analysis adjusted for subjects' BMI, sex, age, and diabetes status with Statsmodel [46] and SciPy [47] packages for Python 3.8.6. $p$-value was adjusted with Benjamini-Hochberg correction. The list of significantly correlated genes was processed using the pathfindr.R package, which allows mapping of major biochemical pathways 
associated with the genes obtained [49]. The full list of all the pathways is available upon request.

\subsubsection{HMGCR SNPs Analysis}

We have used publicly available data from PhenoScanner (http:/ / www.phenoscanner. medschl.cam.ac.uk/, accessed on 23 March 2021) [50,51] to assess the association of rs12916 T-allele SNPs in HMGCR region with diabetes or diabetes-related traits. SNP position is chr5:74656539. We obtained a list of 11 traits; hence, all the $p$-values were adjusted with Bonferroni correction with the factor of 11 .

\subsubsection{Impact of a Genetic HMGCR Variant Lowering LDL Levels on the Circulating Metabolome}

We accessed genetic association results from publicly available data from a GWAS study of circulating levels of 174 blood metabolites [26] for HMGCR variant rs12916, which has previously been linked to lower blood LDL cholesterol [15]. We corrected the $p$-values using the Benjamini-Hochberg method.

\subsection{Observational Study}

The effect of statin treatment on the HOMA-IR index, i.e., an index of insulin resistance, was assessed in 195 individuals (51 individuals on statin therapy and 144 age-, sex-, BMImatched controls) (Table 3). The cohort included healthy subjects as well as patients diagnosed with $\mathrm{T} 2 \mathrm{D}$ or prediabetes.

We performed linear regression analysis with adjustment for age, sex, BMI, HbA1c levels, LDL cholesterol, and diagnosis of diabetes or prediabetes. Continuous variables were log-transformed.

\subsection{In Vitro Studies \\ 4.4.1. Isolation of Human Mature Adipocytes}

Mature adipocytes were isolated from adipose tissue digested for $1 \mathrm{~h}$ at $37^{\circ} \mathrm{C}$ and $105 \mathrm{RPM}$ with $1.2 \mathrm{mg} / \mathrm{mL}$ of collagenase A (Clostridium histolyticum, Roche, Manheim, Germany) in Medium 199 (Gibco, Life Technologies, Paisley, UK) complemented with 4\% bovine serum albumin (BSA, Sigma, St. Louis, MO, USA), $6 \mathrm{mM}$ glucose, and $150 \mathrm{nM}$ adenosine (Sigma, St. Louis, MO, USA), with $\mathrm{pH}$ adjusted to 7.4 with $1 \mathrm{M} \mathrm{NaOH}$ (Sigma, St. Louis, MO, USA). Isolated adipocytes were filtered through $250 \mu \mathrm{m}$ nylon mesh and further used for ex vivo lipolysis and glucose uptake. For lipolysis, isolated adipocytes were washed and diluted with Medium 199 to 3-5\% lipocrit. Glucose uptake experiments were performed with glucose-free Krebs-Ringer-Hepes medium (KRH), supplemented with $4 \%$ BSA, $150 \mathrm{nM}$ adenosine, and $\mathrm{pH}$ 7.4. Isolated adipocytes were washed with $\mathrm{KRH}$ and diluted to $6-7 \%$ lipocrit. Average adipocyte diameter was measured consecutively in 100 adipocytes and the number of cells in the incubation samples as reported previously [52].

\subsubsection{Adipocyte and Adipose Tissue Incubation}

In order to reflect the clinical conditions, the concentration of the drugs for the study was selected according to the reported therapeutic plasma concentrations of simvastatin $(25 \mathrm{nM})$ and its active metabolite simvastatin hydroxy acid $(8 \mathrm{nM})[25,53,54]$. We also used a concentration four times higher to cover all relevant therapeutic concentrations.

Subcutaneous adipose tissue obtained from needle biopsies was incubated in $6 \mathrm{mM}$ glucose Dulbecco's Modified Eagle Medium (DMEM), supplemented with 10\% fetal bovine serum (FBS) and 1\% penicillin-streptomycin without (Control) or with simvastatin ( $25 \mathrm{nM}$ and $100 \mathrm{nM})$ and its active metabolite simvastatin hydroxy acid $(8 \mathrm{nM}$ and $30 \mathrm{nM})$ for $24 \mathrm{~h}$ $(n=16)$. Synthetic glucocorticoid dexamethasone (Dex) was used as a positive control, as it has been reported to reduce the adipose tissue glucose uptake [55,56]. After the incubation with the drugs, adipose tissue was digested as described above, and mature adipocytes 
were isolated for adipocyte glucose uptake and lipolysis measurement. Adipose tissue after the incubation was also washed with ice-cold phosphate-buffered saline (PBS, Medicago, Uppsala, Sweden) and was snap-frozen and transferred to $-80{ }^{\circ} \mathrm{C}$ for further gene and protein expression analysis. Due to the limited amount of adipose tissue obtained per biopsy, not all experiments could be performed in the same tissue from all subjects.

\subsubsection{Statins Effect on Adipocyte Glucose Uptake}

Glucose uptake assessment was performed in adipocytes after incubating adipose tissue with simvastatin as described previously [57]. In short, following the incubation with the drugs, isolated adipocytes were washed with glucose-free KRH medium ( $4 \% \mathrm{BSA}$, $150 \mathrm{nM}$ adenosine, $\mathrm{pH}=7.4$ ). Adipocytes were diluted with $\mathrm{KRH}$ to $6-7 \%$ lipocrit. The lipocrit was transferred to vials kept in a water bath at $37^{\circ} \mathrm{C}$, shaking at 65 RPM. The cells were further stimulated for 15 min without or with physiological and supra-physiological concentrations of insulin $(25 \mu \mathrm{U} / \mathrm{mL}$ and $1000 \mu \mathrm{U} / \mathrm{mL}$, Actrapid, NovoNordisk, Bagsvaerd, Denmark). Following the insulin stimulation, adipocytes were incubated for $45 \mathrm{~min}$ with $0.26 \mathrm{mCi} / \mathrm{L}(0.86 \mu \mathrm{M}) \mathrm{D}-[\mathrm{U}-14 \mathrm{C}]$-glucose (Perkin Elmer, Boston, MA, USA). The reaction was terminated via transferring the cell suspension to pre-cooled vials on ice. To allow the separation of adipocyte cell pellet from the medium, the lipocrit was further centrifuged through $1 \mathrm{~mL}$ of silicone fluid $100 \mathrm{cS}$ (VWR Chemicals, Leuven, Belgium). After that, Ultima Gold scintillation cocktail (Perkin Elmer, Walthman, MA, USA) was added to the cell pellet, and the cellular glucose uptake was calculated as described previously [53], according to the following calculations:

Cell clearance of medium glucose $=\frac{\text { cell-associated radioactivity } \times \text { volume }}{\text { radioactivity of the medium } \times \text { cell number } \times \text { time }}$

Cell-associated radioactivity was measured with Liquid Scintillation Analyser TriCarb 4910 TR (Perkin Elmer, Boston, MA, USA). Glucose uptake was calculated per cell number, and data were normalized to the respective control in each condition.

\subsubsection{Statin Effects on Adipocyte Lipolysis}

After the pre-incubation of adipocytes or adipose tissue with simvastatin, isolated adipocytes were diluted at a lipocrit of 2-3\% with Medium 199 (6 mM glucose, 4\% BSA, $150 \mathrm{nM}$ adenosine, $\mathrm{pH}$ 7.4). The cell suspension was transferred to vials in a water bath at $37^{\circ} \mathrm{C}$, shaking at $65 \mathrm{RPM}$. Adipocytes were stimulated for $10 \mathrm{~min}$ with $0-100 \mathrm{IU} / \mathrm{mL}$ insulin, $37^{\circ} \mathrm{C}, 65 \mathrm{RPM}$. Cells were further co-incubated for $2 \mathrm{~h}$ at $37^{\circ} \mathrm{C}$ without or with $0.5 \mu \mathrm{M}$ $\beta$-receptor agonist isoproterenol (Sigma). The incubation was stopped by transferring the vials on ice. Basal and isoproterenol-stimulated glycerol release was measured as an indicator of lipolysis rate. The glycerol release was detected via colorimetric absorbance at $540 \mathrm{~nm}$ with Free Glycerol Reagent (Sigma) with SpectraMax iD3 (Molecular Devices, San Jose, CA, USA). Glycerol release was normalized to cell number, and all the experiments were performed in triplicates.

\subsubsection{Effect of Statins on Adipocyte Differentiation}

Human Simpson-Golabi-Behmel syndrome (SGBS) adipocytes were kindly provided by Professor Martin Wabitsch (Ulm University Medical Centre, Ulm, Germany). SGBS at passage 3 were expanded in DMEM-F12 supplemented with $33 \mu \mathrm{M}$ biotin (Sigma, St Louis, MO, USA), $17 \mu \mathrm{M}$ pantothenate (Sigma, St Louis, MO, USA), 1\% PEST (Gibco, Life Technologies, Paisley, UK), and 10\% non-heat-inactivated FBS (Gibco, Life Technologies, Paisley, UK). At 80\% confluence, the cells were detached with trypsin (Gibco, Life Technologies, Paisley, UK) and seeded in 12-well plates (Sarstedt, Nümbrecht, Germany) at density 30,000 cells/well. After reaching 90\% confluence, adipocyte differentiation was induced for 4 days with differentiation medium: DMEM-F12 with 1\% PEST (Gibco, Life Technologies, Paisley, UK), $100 \mathrm{nM}$ insulin, $17 \mu \mathrm{M}$ pantothenate, $33 \mu \mathrm{M}$ biotin, $1 \mu \mathrm{M}$ dexamethasone, $1 \mu \mathrm{M}$ rosiglitazone, $250 \mu \mathrm{M}$ 3-isobutyl-1-methylxanthine, $10 \mu \mathrm{g} / \mathrm{mL}$ transferrin, $2 \mathrm{nM}$ 
tri-iodothyronine (T3) (all from Sigma, St Louis, MO, USA). The cell line handling was performed according to the previously reported protocol [54]

The differentiation medium was replaced with a maintenance medium (the same composition as the differentiation medium except for IBMX, dexamethasone, and rosiglitazone) on day 5 . The adipocyte differentiation was sustained until day 14 . The medium was changed every 2 days. The differentiation of adipocytes was estimated on days 0,7 , and 14 post-induction via measuring the expression of adipogenic markers. GUSB was selected as a stable housekeeping gene for gene expression analysis.

In order to assess the adipocyte differentiation rate, on differentiation day 14, the cells were washed with PBS and fixed in $4 \%$ formaldehyde (Histolab, Gothenburg, Sweden) for 15-20 min at RT. The cells were further stained with Hoechst 33342 in PBS and Bodipy 493/503 (4,4-Difluoro-1,3,5,7,8-Pentamethyl-4-Bora-3a,4a-Diaza-s-Indacene; Molecular Probes, OR, USA) dyes for $20 \mathrm{~min}$ at RT for staining the nuclei and lipids, respectively. The images were acquired with ImageXpress Pico Automated Cell Imaging System (Molecular Devices, San Jose, CA, USA). Adipocyte differentiation rate was assessed at differentiation days 7 and 14 by quantifying the number of cells positive for GFP signal from the Bodipy-stained lipids, normalized to total cell number.

\subsubsection{Statin Effects on Adipose Tissue and Adipocyte Gene Expression}

Adipose tissue or adipocytes treated without or with simvastatin was snap-frozen and stored at $-80^{\circ} \mathrm{C}$ for gene expression analysis. RNA extraction was performed with phenol/chloroform extraction method. In brief, adipose tissue or adipocytes were lysed with Trizol Reagent (ThermoFisher, Carlsbad, CA, USA) followed by the addition of chloroform to the homogenate. The aqueous phase was further transferred to isopropanol (Sigma) and incubated to allow RNA precipitation. The pellet was washed three times with 70\% ethanol (Solveco, Roserberg, Sweden) [58]. The RNA was eluted, and its concentration and quality were measured with NanoDrop 2000 spectrophotometer (ThermoFisher Scientific, Rockford, IL, USA). Complementary DNA (cDNA) was reverse-transcribed from $400 \mathrm{ng}$ of RNA with High-Capacity cDNA Reverse Transcription Kit (Applied Biosystems, ThermoFisher Scientific, Foster City, CA, USA). The gene expression analysis was performed with QuantStudio 3 System (Applied Biosystems, ThermoFisher Scientific, Waltham, MA, USA). The Taqman probes (ThermoFisher Scientific) were used for: ADIPOQ, CAV1, IL18, IL1B, IL6, LPL, LEP, PDK4, PPARG, PPARGC1A, SLC2A4, and TFAM. Relative gene expression was normalized to housekeeping gene $18 \mathrm{~S}$ ribosomal RNA (18S rRNA) or GUSB expression. All samples were run in duplicates, and the gene expression was calculated as $2^{-\Delta \Delta \mathrm{Ct}}$ relative to Control, where $\Delta \Delta \mathrm{Ct}=\Delta \mathrm{Ct}_{\text {sample }}-\Delta \mathrm{Ct}$ control and $\Delta \mathrm{Ct}=\mathrm{Ct}_{\text {target gene }}-$ $\mathrm{Ct}_{\text {housekeeping gene. }}$

\subsubsection{Western Blot}

Preadipocytes were collected on days 7 and 14 of differentiation, and total protein was isolated with lysis buffer ( $25 \mathrm{mM}$ Tris-HCl; $0.5 \mathrm{mM}$ EGTA; $25 \mathrm{mM} \mathrm{NaCl} ; 1 \%$ Nonidet P-40; $1 \mathrm{mM} \mathrm{Na}_{3} \mathrm{VO}_{4} ; 10 \mathrm{mM} \mathrm{NaF}$ (all from Sigma, St Louis, MO, USA); $100 \mathrm{nM}$ okadaic acid (Alexis Biochemicals, Lausen, Switzerland), 1X Complete protease inhibitor cocktail (Roche, Indianapolis, IN, USA), and pH 7.4). The protein concentration of the lysates was measured using a BCA protein assay kit (Pierce, Thermo Scientific, Rockford, IL, USA).

Protein lysates $(8-10 \mu \mathrm{g})$ were loaded and separated by SDS-PAGE ( $10 \%$ Mini-Protean TGX Stain-free gels, BioRad, Hercules, CA, USA). This was followed by transfer to nitrocellulose membranes and blocked with 5\% non-fat milk (Sigma) in 0.05\% tween-phosphate buffer saline (PBST, Medicago, Uppsala, Sweden) for $1 \mathrm{~h}$ at room temperature. Membranes were incubated overnight with the primary antibody anti-GLUT4 (1:1000, MA1-83191, Invitrogen, ThermoFisher Scientific, Waltham, MA, USA). Glyceraldehyde-3-phosphate dehydrogenase was detected with anti-GAPDH (1:2000, Millipore, Temecula, CA, USA) was chosen as a loading control protein. After incubation with primary antibody, the membranes were washed with PBST and incubated with horseradish peroxidase-conjugated 
anti-rabbit or anti-mouse (Cell Signaling Technologies, Danvers, MA, USA) secondary antibodies, respectively. Protein bands visualization was done using enhanced chemiluminescence with a high-resolution field and quantified with ChemiDocTM MP System (BioRad, Hercules, CA, USA).

\subsubsection{Incubation of Human Islets and Insulin Determination}

Human islets were supplied by the Islet Transplantation Unit (Department of Radiology, Oncology and Clinical Immunology, Uppsala University Hospital, Uppsala, Sweden) and cultured in CMRL 1066 medium (Invitrogen, Paisley, UK) containing $5.5 \mathrm{mM}$ glucose, $10 \%$ fetal bovine serum, $1 \%$ penicillin-streptomycin and $1 \%$ glutamine (Invitrogen) at $37{ }^{\circ} \mathrm{C}$ and $5 \% \mathrm{CO}_{2}$. Palmitate was prepared as described previously [59]. Human islets were treated with or without $0.5 \mathrm{mM}$ palmitate in the presence or absence of either $20 \mathrm{nM}$ or $100 \mathrm{nM}$ simvastatin (Sigma, St Louis, MO, USA) for $48 \mathrm{~h}$.

Insulin secretion from human islets was measured as described previously [59]. In brief, the islets were perifused in KRBH buffer $(130 \mathrm{mmol} / \mathrm{L} \mathrm{NaCl}, 4.8 \mathrm{mmol} / \mathrm{L} \mathrm{KCl}$, $1.2 \mathrm{mmol} / \mathrm{L} \mathrm{MgSO}_{4}, 1.2 \mathrm{mmol} / \mathrm{L} \mathrm{KH}_{2} \mathrm{PO}_{4}, 1.2 \mathrm{mmol} / \mathrm{L} \mathrm{CaCl}_{2}, 5 \mathrm{mmol} / \mathrm{L} \mathrm{NaHCO}_{3}, 5$ mmol/L HEPES, pH 7.4) supplemented with $1 \mathrm{mg} / \mathrm{mL}$ BSA and $5.5 \mathrm{mM}$ glucose at $37^{\circ} \mathrm{C}$ for $1 \mathrm{~h}$. Following the initial perifusion, aliquots of the medium were collected every $5 \mathrm{~min}$ for $20 \mathrm{~min}$ at $5.5 \mathrm{mM}$ glucose. After this, the medium was replaced with $11 \mathrm{mM}$ glucose and the samples were obtained at 1,2, and $5 \mathrm{~min}$ for the next $20 \mathrm{~min}$. Insulin secretion was measured with enzyme-linked immunosorbent assay (ELISA) as described previously [59].

\subsection{Statistical Analysis}

All data represent mean \pm SEM unless stated otherwise. Transcriptomics, metabolomics, and clinical data analyses were performed using multiple regression analysis with multiple comparison $p$-value adjustment with the Benjamini-Hochberg method. Comparison of the means of more than two groups was performed with repeated-measures One-Way ANOVA test with multiple comparison $p$-value adjustment with False Discovery Rate correction. $*(p<0.05),{ }^{* *}(p<0.01),{ }^{* * *}(p<0.001)$. The means of the two groups were compared using an unpaired parametric or non-parametric test, depending on data distribution. Analyses were performed with Statsmodel 0.5.0 [46] and SciPy 1.7.0 [47] packages for Python 3.8, and GraphPad Prism 9.0 software. Gene enrichment analysis was performed with pathfindr.R package [49]. Data visualization was performed with GraphPad Prism, pathfindr.R package [49] and Inkscape software.

Supplementary Materials: The following are available online at https:/ /www.mdpi.com/article/10 .3390/metabo11090574/s1, Figure S1: Adipose tissue pathways positively associated with HMGCR, Figure S2: Adipose tissue pathways negatively associated with HMGCR. Table S1: List of genes identified in the pathways positively and negatively associated with HMGCR in adipose tissue.

Author Contributions: Conceptualization, M.J.P., T.F. and P.B. (Peter Bergsten); methodology, M.J.P., A.S., B.N.J. and P.B. (Pedro Barbosa).; software, A.S.; formal analysis, A.S., G.F., F.A., J.C. and A.C.; investigation, A.S., B.N.J., P.B. (Pedro Barbosa), J.C. and A.C.; resources, R.K.; data curation, A.S., G.F. and S.S.; writing—original draft preparation, A.S.; writing—review and editing M.J.P., B.N.J., G.F., F.A., P.B. (Pedro Barbosa), R.K., A.C., M.J.P., P.B. (Peter Bergsten), T.F. and J.W.E.; visualization, A.S.; supervision, M.J.P. and J.W.E.; project administration, M.J.P., J.W.E., P.B. (Peter Bergsten), and T.F.; funding acquisition, M.J.P., J.W.E., P.B. (Peter Bergsten), and T.F. All authors have read and agreed to the published version of the manuscript.

Funding: This research was funded by research grants from the Excellence of Diabetes Research in Sweden (EXODIAB), European Commision via the Marie Sklodowska Curie Innovative Training Network TREATMENT (H2020-MSCA-ITN-721236), the Uppsala University Hospital ALF grants, Svenska Sällskapet för Medicinsk Forskning (Swedish Society for Medical Research), the Diabetes Foundation (Swedish Diabetes Association), the Ernfors Foundation, and the P.O Zetterling Foundation. 
Institutional Review Board Statement: The study was conducted according to the guidelines of the Declaration of Helsinki, and approved by the Swedish Ethical Review Authority in Uppsala (DNR 2013/183-494, 2018/385, and 2010/006).

Informed Consent Statement: Informed consent was obtained from all subjects involved in the study.

Data Availability Statement: The data presented in this study are available within the article and Supplementary Material.

Acknowledgments: The authors would like to express their gratitude to all the biopsy donors. We gratefully acknowledge the valuable technical, administrative, analytical contributions and expert advice from co-workers at the Uppsala University and Uppsala University Hospital.

Conflicts of Interest: A.S., B.N.J., G.F., P.B. (Pedro Barbosa), F.A., R.K., J.C., A.C., P.B. (Peter Bergsten), and T.F. have nothing to declare. J.W.E. has received research support from AstraZeneca. S.S. is a full time employee at AstraZeneca R\&D, Gothenburg.

\section{References}

1. Buhaescu, I.; Izzedine, H. Mevalonate pathway: A review of clinical and therapeutical implications. Clin. Biochem. 2007, 40, 575-584. [CrossRef]

2. Betteridge, D.J.; Carmena, R. The diabetogenic action of statins-mechanisms and clinical implications. Nat. Rev. Endocrinol. 2016, 12, 99-110. [CrossRef]

3. Salami, J.A.; Warraich, H.; Valero-Elizondo, J.; Spatz, E.S.; Desai, N.R.; Rana, J.S.; Virani, S.S.; Blankstein, R.; Khera, A.; Blaha, M.J.; et al. National trends in statin use and expenditures in the US adult population from 2002 to 2013: Insights From the Medical Expenditure Panel Survey. JAMA Cardiol. 2017, 2, 56-65. [CrossRef] [PubMed]

4. Jeong, A.; Suazo, K.F.; Wood, W.G.; Distefano, M.D.; Li, L. Isoprenoids and protein prenylation: Implications in the pathogenesis and therapeutic intervention of Alzheimer's disease. Crit. Rev. Biochem. Mol. Biol. 2018, 53, 279-310. [CrossRef]

5. Ahmadi, M.; Amiri, S.; Pecic, S.; Machaj, F.; Rosik, J.; Łos, M.J.; Alizadeh, J.; Mahdian, R.; da Silva Rosa, S.C.; Schaafsma, D.; et al. Pleiotropic effects of statins: A focus on cancer. Biochim. Biophys. Acta Mol. Basis Dis. 2020, 1866, 165968. [CrossRef] [PubMed]

6. Sattar, N.; Preiss, D.; Murray, H.M.; Welsh, P.; Buckley, B.M.; De Craen, A.J.M.; Rao, S.; Seshasai, K.; Davis, B.R.; Pressel, S.L.; et al. Statins and risk of incident diabetes: A collaborative meta-analysis of randomised statin trials. Lancet 2009, 375, 735-742. [CrossRef]

7. Goldstein, M.R.; Mascitelli, L. Do Statins Cause Diabetes? Curr. Diab. Rep. 2013, 13, 381-390. [CrossRef]

8. Preiss, D.; Welsh, P.; Murphy, S.A.; Ho, J.E.; Waters, D.D.; Demicco, D.A.; Cannon, C.P.; Sabatine, M.S. Risk of Incident Diabetes With Intensive-Dose. JAMA 2011, 305, 2556-2564. [CrossRef] [PubMed]

9. Carter, A.A.; Gomes, T. Risk of incident diabetes among patients treated with statins: Population based study. BMJ 2013, 2610, 1-11. [CrossRef]

10. Ridker, P.M.; Pradhan, A.; MacFadyen, J.G.; Libby, P.; Glynn, R.J. Cardiovascular benefits and diabetes risks of statin therapy in primary prevention: An analysis from the JUPITER trial. Lancet 2012, 380, 565-571. [CrossRef]

11. Cederberg, H.; Stančáková, A.; Yaluri, N.; Modi, S.; Kuusisto, J.; Laakso, M. Increased risk of diabetes with statin treatment is associated with impaired insulin sensitivity and insulin secretion: A 6 year follow-up study of the METSIM cohort. Diabetologia 2015, 58, 1109-1117. [CrossRef] [PubMed]

12. Freeman, D.J.; Norrie, J.; Sattar, N.; Neely, R.D.G.; Cobbe, S.M.; Ford, I.; Isles, C.; Lorimer, A.R.; Macfarlane, P.W.; McKillop, J.H.; et al. Pravastatin and the development of diabetes mellitus: Evidence for a protective treatment effect in the West of Scotland coronary prevention study. Circulation 2001, 103, 357-362. [CrossRef] [PubMed]

13. Schachter, M. Chemical, pharmacokinetic and pharmacodynamic properties of statins: An update. Fundam. Clin. Pharmacol. 2005, 19, 117-125. [CrossRef]

14. Swerdlow, D.I.; Preiss, D.; Kuchenbaecker, K.B.; Holmes, M.V.; Engmann, J.E.L.; Shah, T.; Sofat, R.; Stender, S.; Johnson, P.C.D.; Scott, R.A.; et al. HMG-coenzyme A reductase inhibition, type 2 diabetes, and bodyweight: Evidence from genetic analysis and randomised trials. Lancet 2015, 385, 351-361. [CrossRef]

15. Perego, C.; Da Dalt, L.; Pirillo, A.; Galli, A.; Catapano, A.L.; Norata, G.D. Cholesterol metabolism, pancreatic $\beta$-cell function and diabetes. Biochim. Biophys. Acta Mol. Basis Dis. 2019, 1865, 2149-2156. [CrossRef] [PubMed]

16. Xia, F.; Xie, L.; Mihic, A.; Gao, X.; Chen, Y.; Gaisano, H.Y.; Tsushima, R.G. Inhibition of cholesterol biosynthesis impairs insulin secretion and voltage-gated calcium channel function in pancreatic $\beta$-cells. Endocrinology 2008, 149, 5136-5145. [CrossRef] [PubMed]

17. Sampson, U.K.; Linton, M.F.; Fazio, S. Are statins diabetogenic? Curr. Opin. Cardiol. 2011, 26, 342-347. [CrossRef]

18. Yaluri, N.; Modi, S.; Kokkola, T. Simvastatin induces insulin resistance in L6 skeletal muscle myotubes by suppressing insulin signaling, GLUT4 expression and GSK-3 $\beta$ phosphorylation. Biochem. Biophys. Res. Commun. 2016, 480, 194-200. [CrossRef]

19. Sanvee, G.M.; Panajatovic, M.V.; Bouitbir, J.; Krähenbühl, S. Mechanisms of insulin resistance by simvastatin in C2C12 myotubes and in mouse skeletal muscle. Biochem. Pharmacol. 2019, 164, 23-33. [CrossRef] 
20. Balaz, M.; Becker, A.S.; Balazova, L.; Straub, L.; Müller, J.; Gashi, G.; Maushart, C.I.; Sun, W.; Dong, H.; Moser, C.; et al. Inhibition of Mevalonate Pathway Prevents Adipocyte Browning in Mice and Men by Affecting Protein Prenylation. Cell Metab. 2019, 29, 901-916.e8. [CrossRef]

21. Yeh, Y.S.; Jheng, H.F.; Iwase, M.; Kim, M.; Mohri, S.; Kwon, J.; Kawarasaki, S.; Li, Y.; Takahashi, H.; Ara, T.; et al. The Mevalonate Pathway Is Indispensable for Adipocyte Survival. iScience 2018, 9, 175-191. [CrossRef] [PubMed]

22. Nakata, M.; Nagasaka, S.; Kusaka, I.; Matsuoka, H.; Ishibashi, S.; Yada, T. Effects of statins on the adipocyte maturation and expression of glucose transporter 4 (SLC2A4): Implications in glycaemic control. Diabetologia 2006, 49, 1881-1892. [CrossRef] [PubMed]

23. Maeda, T.; Horiuchi, N. Simvastatin suppresses leptin expression in 3T3-L1 adipocytes via activation of the cyclic AMP-PKA pathway induced by inhibition of protein prenylation. J. Biochem. 2009, 145, 771-781. [CrossRef] [PubMed]

24. Björkhem-Bergman, L.; Lindh, J.D.; Bergman, P. What is a relevant statin concentration in cell experiments claiming pleiotropic effects? Br. J. Clin. Pharmacol. 2011, 72, 164-165. [CrossRef]

25. Lotta, L.A.; Pietzner, M.; Stewart, I.D.; Wittemans, L.B.L.; Li, C.; Bonelli, R.; Raffler, J.; Biggs, E.K.; Oliver-Williams, C.; Auyeung, V.P.W.; et al. A cross-platform approach identifies genetic regulators of human metabolism and health. Nat. Genet. 2021, 53, 54-64. [CrossRef]

26. Mollazadeh, H.; Tavana, E.; Fanni, G.; Bo, S.; Banach, M.; Pirro, M.; von Haehling, S.; Jamialahmadi, T.; Sahebkar, A. Effects of statins on mitochondrial pathways. J. Cachexia. Sarcopenia Muscle 2021. [CrossRef]

27. Holmes, G.P.; McCormick, J.B.; Trock, S.C.; Chase, R.A.; Lewis, S.M.; Mason, C.A.; Hall, P.A.; Brammer, L.S.; Perez-Oronoz, G.I.; McDonnell, M.K.; et al. Lassa fever in the United States. N. Eng. J. Med. 1990, 323, 1120-1123.

28. Conde, K.; Roy, S.; Freake, H.C.; Newton, R.S.; Fernandez, M.L. Atorvastatin and simvastatin have distinct effects on hydroxy methylglutaryl-CoA reductase activity and mRNA abundance in the guinea pig. Lipids 1999, 34, 1327-1332. [CrossRef]

29. Chen, Y.; Xu, S.C.; Duan, R.D. Mevalonate inhibits acid sphingomyelinase activity, increases sphingomyelin levels and inhibits cell proliferation of HepG2 and Caco-2 cells. Lipids Health Dis. 2015, 14, 1-8. [CrossRef]

30. Yanagita, T.; Yamamoto, K.; Ishida, S.; Sonda, K.; Morito, F.; Saku, K.; Sakai, T. Effects of simvastatin, a cholesterol synthesis inhibitor, on phosphatidylcholine synthesis in HepG2 cells. Clin. Ther. 1994, 16, 200-208.

31. Clore, J.N.; Harris, P.A.; Li, J.; Azzam, A.; Gill, R.; Zuelzer, W.; Rizzo, W.B.; Blackard, W.G. Changes in phsophatidylcholine fatty acid composition are associated with altered skeletal muscle insulin responsiveness in normal man. Metabolism 2000, 49, 232-238. [CrossRef]

32. Chang, W.; Hatch, G.M.; Wang, Y.; Yu, F.; Wang, M. The relationship between phospholipids and insulin resistance: From clinical to experimental studies. J. Cell Mol. Med. 2019, 24, 702-710. [CrossRef]

33. Zhao, J.; Zhu, Y.; Hyun, N.; Zeng, D.; Uppal, K.; Tran, V.T.; Yu, T.; Jones, D.; He, J.; Lee, E.T.; et al. Novel metabolic markers for the risk of diabetes development in American Indians. Diabetes Care 2015, 38, 220-227. [CrossRef]

34. Virtanen, K.A.; Lönnroth, P.; Parkkola, R.; Peltoniemi, P.; Asola, M.; Viljanen, T.; Tolvanen, T.; Knuuti, J.; Rönnemaa, T.; Huupponen, R.; et al. Glucose uptake and perfusion in subcutaneous and visceral adipose tissue during insulin stimulation in nonobese and obese humans. J. Clin. Endocrinol. Metab. 2002, 87, 3902-3910. [CrossRef]

35. Henriksbo, B.D.; Tamrakar, A.K.; Xu, J.; Duggan, B.M.; Cavallari, J.F.; Phulka, J.; Stampfli, M.R.; Ashkar, A.A.; Schertzer, J.D. Statins promote interleukin-1 $\beta$-dependent adipocyte insulin resistance through lower prenylation, not cholesterol. Diabetes 2019, 68, 1441-1448. [CrossRef]

36. Khan, T.; Hamilton, M.P.; Mundy, D.I.; Chua, S.C.; Scherer, P.E. Impact of simvastatin on adipose tissue: Pleiotropic effects in vivo. Endocrinology 2009, 150, 5262-5272. [CrossRef]

37. Koh, K.K.; Quon, M.J.; Han, S.H.; Lee, Y.; Ahn, J.Y.; Kim, S.J.; Koh, Y.; Shin, E.K. Simvastatin Improves Flow-Mediated Dilation but Reduces Adiponectin Levels and Insulin Sensitivity in Hypercholesterolemic Patients. Diabetes Care 2008, 31, 776-782. [CrossRef]

38. Henriksbo, B.D.; Lau, T.C.; Cavallari, J.F.; Denou, E.; Chi, W.; Lally, J.S.; Crane, J.D.; Duggan, B.M.; Foley, K.P.; Fullerton, M.D.; et al. Fluvastatin causes NLRP3 inflammasome-mediated adipose insulin resistance. Diabetes 2014, 63, 3742-3747. [CrossRef] [PubMed]

39. Martinez-Santibañez, G.; Nien-Kai Lumeng, C. Macrophages and the regulation of adipose tissue remodeling. Annu. Rev. Nutr. 2014, 34, 57-76. [CrossRef] [PubMed]

40. Sugiyama, T.; Tsugawa, Y.; Tseng, C.H.; Kobayashi, Y.; Shapiro, M.F. Different time trends of caloric and fat intake between statin users and nonusers among US adults gluttony in the time of statins? JAMA Intern. Med. 2014, 174, 1038-1045. [CrossRef] [PubMed]

41. Staaf, J.; Ubhayasekera, S.J.K.A.; Sargsyan, E.; Chowdhury, A.; Kristinsson, H.; Manell, H.; Bergquist, J.; Forslund, A.; Bergsten, P. Initial hyperinsulinemia and subsequent $\beta$-cell dysfunction is associated with elevated palmitate levels. Pediatr. Res. 2016, 80, 267-274. [CrossRef]

42. Urbano, F.; Bugliani, M.; Filippello, A.; Scamporrino, A.; Di Mauro, S.; Di Pino, A.; Scicali, R.; Noto, D.; Rabuazzo, A.M.; Averna, M.; et al. Atorvastatin but not pravastatin impairs mitochondrial function in human pancreatic islets and rat $\beta$-cells. Direct effect of oxidative stress. Sci. Rep. 2017, 7, 11863. [CrossRef]

43. Takei, S.; Nagashima, S.; Takei, A.; Yamamuro, D.; Wakabayashi, T.; Murakami, A.; Isoda, M.; Yamazaki, H.; Ebihara, C.; Takahashi, M.; et al. B-cell-specific deletion of hmg-coa (3-hydroxy-3-methylglutaryl-coenzyme a) reductase causes overt diabetes due to reduction of b-cell mass and impaired insulin secretion. Diabetes 2020, 69, 2352-2363. [CrossRef] 
44. Shen, L.; Gu, Y.; Qiu, Y.; Cheng, T.; Nie, A.; Cui, C.; Fu, C.; Li, T.; Li, X.; Fu, L.; et al. Atorvastatin targets the islet mevalonate pathway to dysregulate mtor signaling and reduce b-cell functional mass. Diabetes 2020, 69, 48-59. [CrossRef]

45. Rorsman, P.; Ashcroft, F.M. Pancreatic $\beta$-cell electrical activity and insulin secretion: Of mice and men. Physiol. Rev. 2018, 98, 117-214. [CrossRef] [PubMed]

46. Seabold, S.; Perktold, J. Statsmodels: Econometric and Statistical Modeling with Python. In Proceedings of the 9th Python In Science Conferences (SCIPY 2010), Austin, TX, USA, 28 June-3 July 2010; pp. 92-96. [CrossRef]

47. Virtanen, P.; Gommers, R.; Oliphant, T.E.; Haberland, M.; Reddy, T.; Cournapeau, D.; Burovski, E.; Peterson, P.; Weckesser, W.; Bright, J.; et al. SciPy 1.0: Fundamental algorithms for scientific computing in Python. Nat. Methods 2020, 17, 261-272. [CrossRef] [PubMed]

48. Pereira, M.J.; Skrtic, S.; Katsogiannos, P.; Abrahamsson, N.; Sidibeh, C.O.; Dahgam, S.; Månsson, M.; Risérus, U.; Kullberg, J.; Eriksson, J.W. Impaired adipose tissue lipid storage, but not altered lipolysis, contributes to elevated levels of NEFA in type 2 diabetes. Degree of hyperglycemia and adiposity are important factors. Metabolism 2016, 65, 1768-1780. [CrossRef] [PubMed]

49. Ulgen, E.; Ozisik, O.; Sezerman, O.U. PathfindR: An R package for comprehensive identification of enriched pathways in omics data through active subnetworks. Front. Genet. 2019, 10,1-33. [CrossRef]

50. Staley, J.R.; Blackshaw, J.; Kamat, M.A.; Ellis, S.; Surendran, P.; Sun, B.B.; Paul, D.S.; Freitag, D.; Burgess, S.; Danesh, J.; et al. PhenoScanner: A database of human genotype-phenotype associations. Bioinformatics 2016, 32, 3207-3209. [CrossRef]

51. Kamat, M.A.; Blackshaw, J.A.; Young, R.; Surendran, P.; Burgess, S.; Danesh, J.; Butterworth, A.S.; Staley, J.R. PhenoScanner V2: An expanded tool for searching human genotype-phenotype associations. Bioinformatics 2019, 35, 4851-4853. [CrossRef]

52. Lundgren, M.; Svensson, M.; Lindmark, S.; Renström, F.; Ruge, T.; Eriksson, J.W. Fat cell enlargement is an independent marker of insulin resistance and "hyperleptinaemia". Diabetologia 2007, 50, 625-633. [CrossRef] [PubMed]

53. Yu, Z.W.; Jansson, P.A.; Posner, B.I.; Smith, U.; Eriksson, J.W. Peroxovanadate and insulin action in adipocytes from NIDDM patients. Evidence against a primary defect in tyrosine phosphorylation. Diabetologia 1997, 40, 1197-1203. [CrossRef] [PubMed]

54. Fischer-Posovszky, P.; Newell, F.S.; Wabitsch, M.; Tornqvist, H.E. Human SGBS cells-A unique tool for studies of human fat cell biology. Obes. Facts 2008, 1, 184-189. [CrossRef] [PubMed]

55. Sidibeh, C.O.; Pereira, M.J.; Abalo, X.M.; Boersma, G.J.; Skrtic, S.; Lundkvist, P.; Katsogiannos, P.; Hausch, F.; Castillejo-López, C.; Eriksson, J.W. FKBP5 expression in human adipose tissue: Potential role in glucose and lipid metabolism, adipogenesis and type 2 diabetes. Endocrine 2018, 62, 116-128. [CrossRef]

56. Lundgren, M.; Burén, J.; Ruge, T.; Myrnäs, T.; Eriksson, J.W. Glucocorticoids down-regulate glucose uptake capacity and insulin-signaling proteins in omental but not subcutaneous human adipocytes. J. Clin. Endocrinol. Metab. 2004, 89, $2989-2997$. [CrossRef]

57. Sarsenbayeva, A.; Marques-Santos, C.M.; Thombare, K.; Di Nunzio, G.; Almby, K.E.; Lundqvist, M.; Eriksson, J.W.; Pereira, M.J. Effects of second-generation antipsychotics on human subcutaneous adipose tissue metabolism. Psychoneuroendocrinology 2019, 110, 104445. [CrossRef]

58. Rio, D.C.; Ares, M.; Hannon, G.J.; Nilsen, T.W. Purification of RNA using TRIzol (TRI Reagent). Cold Spring Harb. Protoc. 2010, 5, 1-4. [CrossRef]

59. Chowdhury, A.I.; Bergsten, P. GLP-1 analogue recovers impaired insulin secretion from human islets treated with palmitate via down-regulation of SOCS2. Mol. Cell. Endocrinol. 2017, 439, 194-202. [CrossRef] 